US Army Corps

of Engineers ${ }_{\circledast}$

Engineer Research and

Development Center

\title{
Literature Review of Nearshore Berms
}

Katherine E. Brutsché, Brian C. McFall, Duncan B. Bryant, and Ping Wang

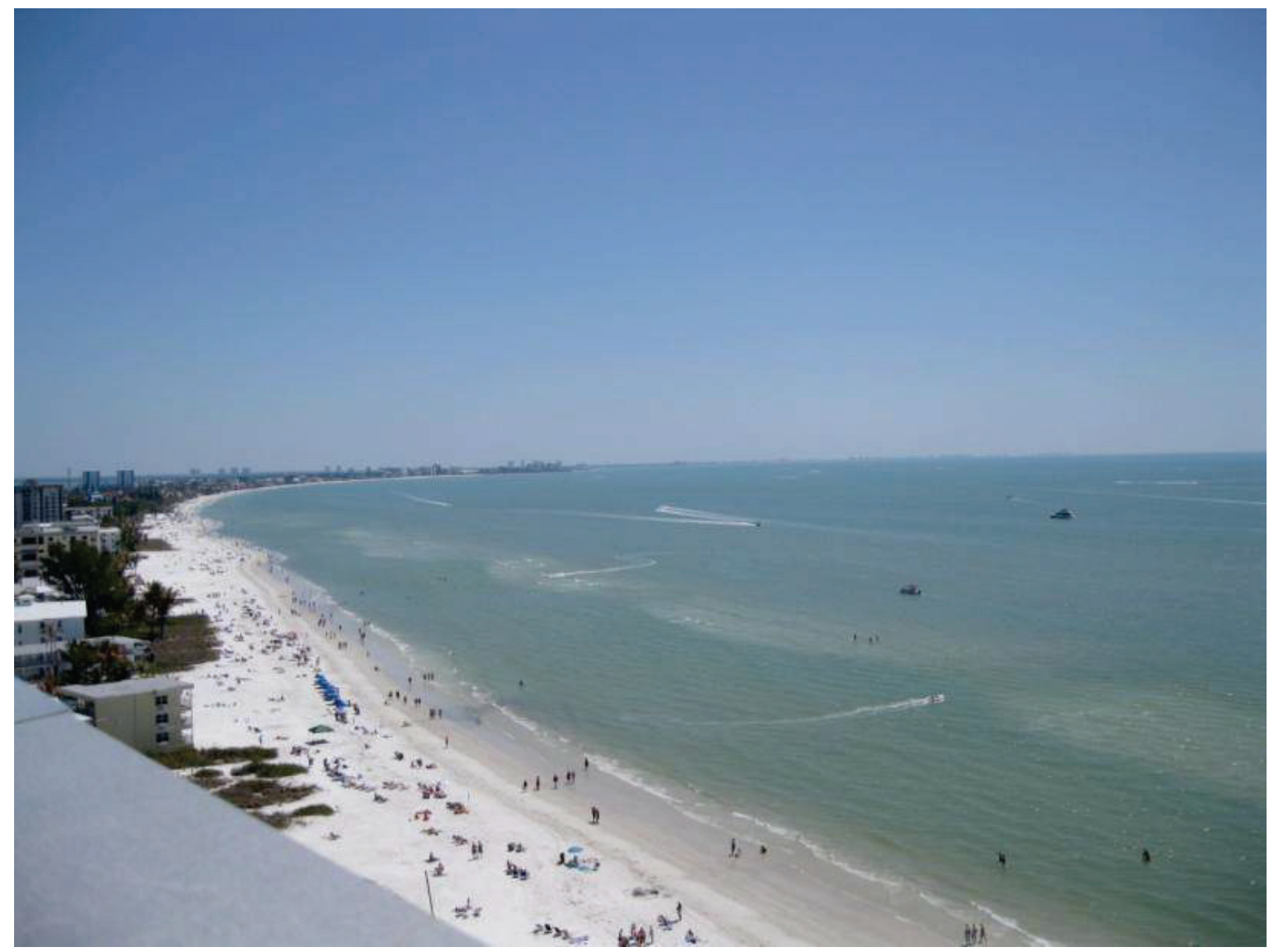


The U.S. Army Engineer Research and Development Center (ERDC) solves the nation's toughest engineering and environmental challenges. ERDC develops innovative solutions in civil and military engineering, geospatial sciences, water resources, and environmental sciences for the Army, the Department of Defense, civilian agencies, and our nation's public good. Find out more at www.erdc.usace.army.mil.

To search for other technical reports published by ERDC, visit the ERDC online library at http://acwc.sdp.sirsi.net/client/default. 


\section{Literature Review of Nearshore Berms}

Katherine E. Brutsché, Brian C. McFall, Duncan B. Bryant

Coastal and Hydraulics Laboratory

U.S. Army Engineer Research and Development Center

3909 Halls Ferry Road

Vicksburg, MS 39180-6199

Ping Wang

School of Geosciences

University of South Florida

4202 E. Fowler Ave.

Tampa, FL 33620

Final report

Approved for public release; distribution is unlimited.

Prepared for U.S. Army Engineer Research and Development Center 3909 Halls Ferry Road

Vicksburg, MS 39180-6199

Under CIRP Inlet Geomorphology Work Unit (476927) 


\section{Abstract}

This Coastal and Hydraulics Engineering special report is a general overview of the current state of nearshore berm placement research. The report describes current design guidance for nearshore berm placement, as well as the major findings of existing numerical and physical modeling studies. Field experiments are also summarized. Numerical and physical models are important as they help to illustrate in greater detail the morphological evolution and hydrodynamic effects the berm has on the surrounding area. Physical models allow for two- and three-dimensional illustration of these concepts. Field studies show that onshore migration of active berms occurs and the tendency of nearshore berms to act as a submerged breakwater. Although many field and modeling studies exist to assess the morphologic and sedimentologic evolution of berms, a need for more detailed understanding of the processes associated with these types of nourishments still exists. More data to predict where material is going, how the existing adjacent morphologic features respond to the placement, and how long the material will remain in place (or its intended location) are necessary to answer stakeholder questions for these types of placements.

DISCLAIMER: The contents of this report are not to be used for advertising, publication, or promotional purposes. Citation of trade names does not constitute an official endorsement or approval of the use of such commercial products. All product names and trademarks cited are the property of their respective owners. The findings of this report are not to be construed as an official Department of the Army position unless so designated by other authorized documents. 


\section{Contents}

Abstract.................................................................................................................................. if

Figures and Tables........................................................................................................................

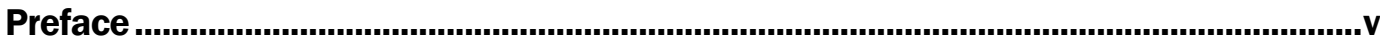

Unit Conversion Factors.................................................................................................vi

1 Introduction .................................................................................................. 1

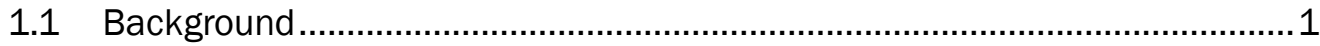

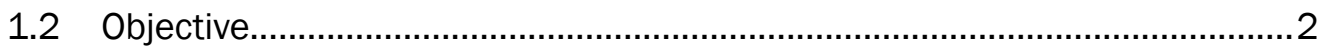

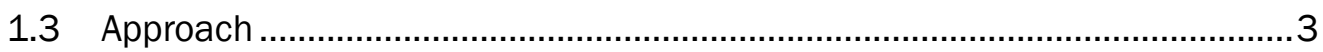

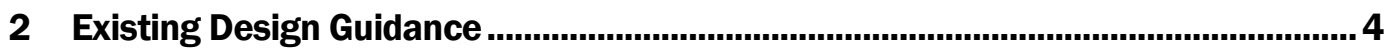

2.1 Determining nearshore berm mobility ...................................................... 4

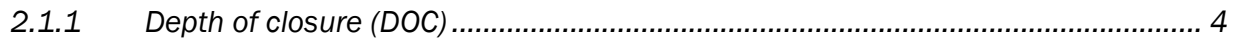

2.1.2 Active (or Feeder) vs. stable berms................................................................... 6

2.1.3 Mobility predictions using morphologic and hydrodynamic parameters ................. 8

2.2 Other design and placement considerations.............................................10

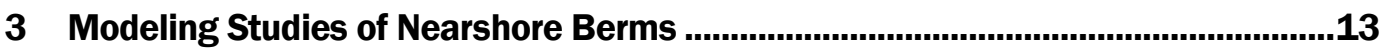

3.1 Numerical modeling studies ................................................................. 13

3.1.1 Sediment Mobility Tool (SMT) ........................................................................... 13

3.1.2 Other predictive numerical models................................................................... 15

3.1.3 Other numerical model studies .................................................................... 17

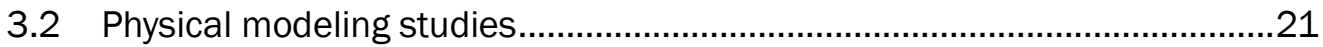

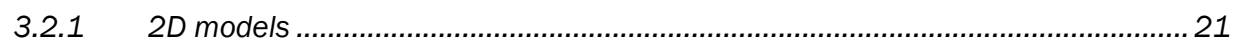

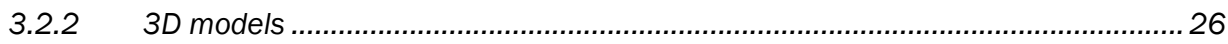

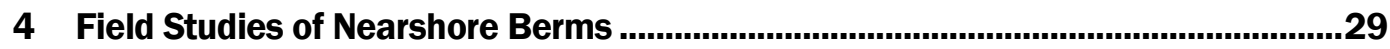

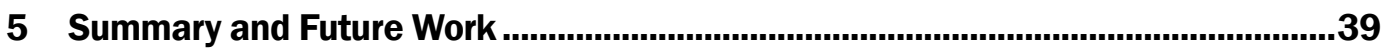

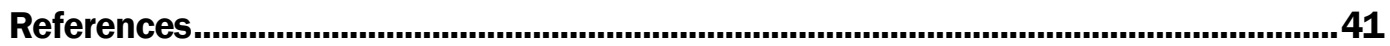

\section{Report Documentation Page}




\section{Figures and Tables}

\section{Figures}

Figure 1. Shore perpendicular profile zonations (Hallermeier 1981).

Figure 2. Nearshore berm stability graph illustrating the difference between active and stable berms in deep or shallow water (from Beck et al. [2012], modified from Hands and Allison [1991]).

Figure 3. Histogram of the calculated maximum bed shear stress at a depth of 8 m (from McFall et al. 2016).

Figure 4. Histogram of the calculated near bottom velocity at a depth of $8 \mathrm{~m}$ (from McFall et al. 2016).

Figure 5. CMS modeling of the Fort Myers Beach nearshore berm illustrating (A) wave dissipation across the berm, (B) longshore currents along the berm crest, and (C) flow through the gaps in the berm (from Brutsché 2014).

Figure 6. (A) Isometric view of the LSTF during a sediment transport experiment (Hamilton et al. 2001) and (B) plan view of the LSTF.

Figure 7. Results from Smith et al. (2015) showing downstream migration of berms.

Figure 8. Average variance from the average profile of the study area (Brutsché et al. 2014; Brutsché 2014).

Figure 9. Dry beach width and volume change between April 2010 and May 2013 (Brutsché et al. 2014; Brutsché 2014).

\section{Tables}

Table 1. Summary of existing artificial berms/mounds (Wang et al. 2013). A portion of this table was obtained from Otay (1994). 


\section{Preface}

This study was conducted for the U.S. Army Engineer Research and Development Center (ERDC) under the USACE Coastal Inlets Research and Dredging Operations and Environmental Research Programs, CIRP Inlet Geomorphology Work Unit (476927). The technical monitors were Ms. Tanya Beck, Program Manager, Coastal Inlets Research Program, and Dr. Todd S. Bridges, Program Manager, Dredging Operations and Environmental Research Program.

The work was performed by the Coastal Engineering and Coastal Processes Branches of the Navigation and Flood and Storm Protection Divisions, U.S. Army Engineer Research and Development Center, Coastal and Hydraulics Laboratory (ERDC-CHL).

At the time of publication of this report, Ms. Lauren Dunkin was Chief, Coastal Engineering Branch; Ms. Ashley E. Frey was Chief, Coastal Processes Branch; Dr. Jackie S. Pettway was Chief, Navigation Division, and Dr. Cary Talbot was Chief, Flood and Coastal Division; Mr. Eddie Wiggins was the ERDC Technical Director for Navigation Research, Development, and Technology Transfer portfolio. The Deputy Director of ERDC-CHL was Mr. Jeffrey R. Eckstein, and the Director was Dr. Ty V. Wamsley.

The Commander of ERDC was COL Ivan P. Beckman, and the Director was Dr. David W. Pittman. 


\section{Unit Conversion Factors}

\begin{tabular}{|l|l|l|}
\hline Multiply & By & To Obtain \\
\hline cubic yard $\left(\mathrm{yd}^{3}\right)$ & 0.7645549 & cubic meters \\
\hline feet & 0.3048 & meters \\
\hline yards & 0.9144 & meters \\
\hline
\end{tabular}




\section{Introduction}

\subsection{Background}

Navigable depths in channels and inlets are regularly sustained through periodic Operation \& Maintenance dredging. Often, it is the goal to beneficially use the dredged material as part of Engineering With Nature and Regional Sediment Management (RSM) practices. Beneficial use is one technique to allow sediment to remain in the littoral zone so that it may nourish the beach and nearshore. In contrast, methods such as offshore disposal of the material removes it from the system, thereby potentially depleting the littoral zone of sediment. In the coastal zone, there are two major beneficial use practices currently employed along sandy beaches: direct placement of material on the beach in the form of a beach nourishment or placement of material in the nearshore in the form of a nearshore berm.

A beach nourishment is the placement of material on the beach to advance the shoreline seaward and protect against inundation of the coastline by storm and wave action as well as for recreational purposes (Finkl and Walker 2005) whereas nearshore berm nourishments are the placement of material in the nearshore in the form of an elongate bar or a mound. Nearshore berm nourishments can be the preferred method of beneficial use because often state regulations require more strict grain size compatibility between native and dredged material for beach nourishments than nearshore berm nourishments. Additionally, nearshore berm nourishments are generally less costly to build, easier to construct, and have fewer environmental concerns such as their potential to affect sea turtle and shore bird nesting.

Nearshore berms offer a placement option for mixed sediment (e.g., mostly sand with varying amounts of fines) that is not considered beach quality according to individual state criteria. Sand remains in the littoral zone, with the potential to reduce waves in the lee of the berm, sheltering the adjacent beach. Ideally, through proper design, the sand fraction of the material will move onshore, and the fine material will winnow out and be dispersed offshore. In addition, as compared to deep-water placement or confined placement, pumping or hopper dredge placement in the nearshore can be less costly. Finally, depending on the site and placement, 
berms can offer recreational benefits such as surfable waves and shallower nearshore areas for beach-goers. For these reasons, nearshore berms have become an increasingly utilized beneficial use practice. However, there may be aesthetic detriments to nearshore berms, such as stagnant water if the berm migrates onshore and becomes intertidal, temporary deposition of fine materials in the trough landward of the berm, and difficulty in getting beach watercraft offshore over a shallow bar (Wang et al. 2013). Better guidance for berm design and evolution is needed to maximize the benefits of nearshore berms while minimizing negative impacts.

Systematic studies on design considerations for nearshore berm placement were primarily conducted in the late-1980s to mid-1990s, with several studies (e.g., Hands and Bradley 1990; Hands and Deloach 1984; Hands and Allison 1991; Scheffner 1991; Allison and Pollock 1993; McLellan and Kraus 1991; McLellan 1990 a,b) funded by the U.S. Army Corps of Engineers (USACE), Dredging Research Program (DRP). These studies resulted in guidance for evaluating the general stability of a nearshore berm (e.g., whether the entire placement would be stable or mobile). Recognizing the strong control of site-specific conditions on berm performance, nearly all of the studies recommended detailed field monitoring. The developments of the berm performance criteria and design guidelines were largely based on the findings of Hallermeier's (1981a,b) study on profile zonation and Larson and Kraus' (1992 and 1994) studies on bar morphodynamics. However, various site-specific issues associated with berm nourishments need to be carefully addressed. Key issues include whether and how the artificial berm will move onshore or offshore and the processes that are associated with the berm movement and how the coarser and finer fractions of the placed sediment will redistribute.

\subsection{Objective}

The following special report serves to summarize the current state of knowledge of nearshore berm placement through an extensive literature review of previous studies. Studies include existing design guidance, case studies, and various modeling studies. The report also includes potential paths forward in the research of nearshore placement. 


\subsection{Approach}

The report is divided into different sections to summarize the state of the practice in nearshore placement, including a path forward. Chapter 1 gives a brief background of nearshore placement, and Chapter 2 gives examples of existing design guidance. Chapter 3 summarizes many numerical and physical modeling studies. Chapter 4 highlights previous case studies, and finally, Chapter 5 summarizes the review and outlines potential paths forward for future research. 


\section{Existing Design Guidance}

Beginning in the 1990s, the U.S. Army Corps of Engineers (USACE) has produced several design guidance documents for nearshore berm placement. Perhaps the most important design parameter to consider is whether or not the material will move once it is placed in the nearshore, which is often determined based on depth of placement, wave characteristics of the region, and sediment grain size. In addition to nearshore berm mobility, the USACE also produced several guidance documents on several factors including length, width, side slopes, timing of placement, etc. The following section first details the initial guidance and updated methods on determining berm mobility, followed by a discussion of other placement considerations that are summarized in the series of U.S. Army Engineer Research and Development Center (ERDC) technical notes.

\subsection{Determining nearshore berm mobility}

\subsubsection{Depth of closure (DOC)}

In order to discuss existing design guidance of nearshore placement of sediment, specifically whether or not the berm will be mobile, it is first important to understand the concept of DOC. As defined by Kraus et al. (1998), the "depth of closure for a given or characteristic time interval is the most landward depth seaward of which there is no significant change in bottom elevation and no significant net sediment transport between the nearshore and the offshore." Generally, the DOC can be defined as the depth at which time-series profiles converge (i.e., there is no elevation change) as it is challenging to quantify sediment transport over a large spatial and temporal domain.

From wave tank and field studies, Hallermeier (1978, 1981a, 1981b, 1983) created the first theoretical definition of the DOC. He defined three separate profile zones related to the critical value of a Froude number describing the threshold of erosive sand bed agitation by wave action: the littoral zone, the shoal zone, and the offshore zone (Figure 1). The boundaries of the zones were empirically derived from local sediment characteristics and summary statistics of annual wave climate and are defined as the Inner DOC and the Outer DOC. The Inner DOC ( $D_{\text {inner }}$ ) marks the seaward extent of the littoral zone, which "extends to the 
seaward limit of intense bed activity caused by extreme near-breaking waves and breaker related currents" (Hallermeier 1981a). The Inner DOC was found to be related to the effective wave height, $H_{e}$, and the associated wave period, $T_{e}$, and $g$, the gravitational constant through the following equation:

$$
D_{\text {inner }}=d_{l}=2.28 H_{e}-68.5\left(\frac{H_{e}^{2}}{g T_{e}^{2}}\right)
$$

The effective wave height is defined as wave conditions that exceed only 12 hours out of a single year (or the greatest $0.137 \%$ waves in a year). It is related to the mean annual significant wave height, $\overline{H_{s}}$, and the standard deviation of the mean annual significant wave height, $\sigma_{s}$, through the following equation:

$$
H_{e}=\overline{H_{s}}+5.6 \sigma_{s}
$$

Using the relationship between the effective wave height and the mean annual significant wave height yields another definition of the Inner DOC as

$$
D_{\text {inner }}=d_{l}=2 \overline{H_{s}}+11 \sigma_{s}
$$

The Outer DOC marks the seaward extent of the shoal zone, where "expected surface waves are likely to cause little sand transport and the waves have neither a strong nor negligible effect on the bed" (Hallermeier 1981b). Hallermeier found that unlike the Inner DOC, the Outer DOC can be related to grain size through the equation

$$
D_{\text {outer }}=d_{i}=\left(\overline{H_{s}}-0.3 \sigma_{s}\right) \overline{T_{s}}\left(\frac{g}{5000 D}\right)^{0.5}
$$

where $D$, or $d_{5 o}$, is the median grain size of the sediment and $\bar{T}_{S}$ is the period associated with the annual mean significant wave height. The term $\overline{H_{s}}-0.3 \sigma_{s}$ in Equation 4 is also defined as $H_{s m}$, or the yearly median significant wave height. 
Figure 1. Shore perpendicular profile zonations (Hallermeier 1981).

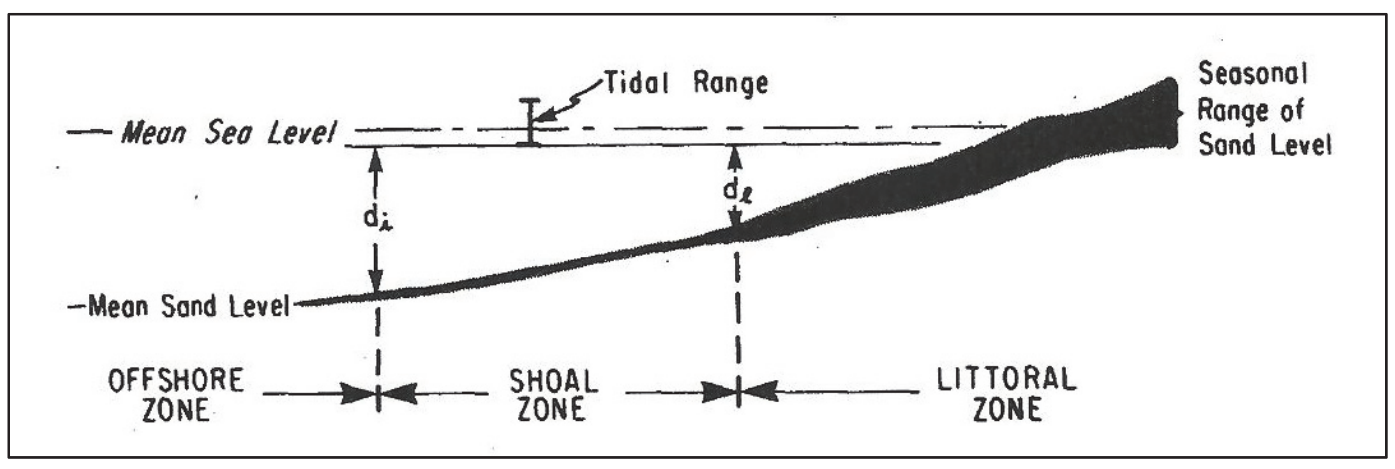

Birkemeier (1985) reevaluated the Hallermeier equation for the Inner DOC using monthly bathymetric surveys from June 1981 to December 1982 at the USACE Field Research Facility (FRF) in Duck, NC. Through his study, he found a better approximation for the DOC to be

$$
D_{\text {inner }}=d_{l}=1.75 H_{e}-57.9\left(\frac{H_{e}^{2}}{g T_{e}^{2}}\right)
$$

The DOC is an important concept used in many coastal engineering projects. To that end, the USACE Coastal Inlets Research Program (CIRP) has calculated and mapped DOCs around the United States coastlines, including the Great Lakes, using both the Hallermeier and Birkemeier equations. (Details of the methodology and data availability can be found in Brutsché et al. [2016]).

\subsubsection{Active (or Feeder) vs. stable berms}

One design parameter to consider is whether or not the sediment that makes up a nearshore berm will mobilize once the material is placed. The two types of nearshore berms have been previously distinguished as active vs. stable berms (Hands and Allison 1991) or feeder vs. stable berms (McLellan and Kraus 1991). Hands and Allison (1991) defined active berms as those that show significant movement within the first few months while stable berms retain most of their original volume and remain at the placement site for years. Similarly, according to McLellan and Kraus (1991), a feeder berm is placed in sufficiently shallow water and with relatively high relief and induces wave breaking, especially during storm conditions, therefore significantly reducing the wave energy arriving at the shoreline. A feeder berm also tends to migrate onshore under accretionary wave conditions. A stable berm is designed to remain largely stationary. It may attenuate larger storm waves. Generally, feeder berms should be 
composed of beach quality sand. If a stable berm consists of beach quality sand, it can serve as a stockpile for future beach nourishments. Both types of berms have the indirect benefits associated with them including potentially attenuating waves, thereby reducing erosion at the shoreline, and in the case of stable berms, serving as a sediment stockpile. Feeder or active berms have the additional direct benefit of potentially adding sediment to the dry beach (McLellan et al. 1990).

Hands and Allison (1991) investigated ways to determine whether a nearshore berm would be active or stable using two separate methods. For both methods, 11 nearshore berms were studied to determine whether onshore migration occurred. The first method determines mobility as a function of effective wave energy. Wave Information Study (WIS) hindcast data were transformed to the base of each of the 11 berm sites using a Texel, MARSEN, and ARSLOE (TMA)-type relationship. The maximum near-bed, wave-induced velocity was then calculated at each of the sites. Generally, berms that experienced higher maximum near-bed velocities were found to be active while those that experienced the lower velocities were stable. The near-bed velocities that have a chance of nonexceedance at the upper 75 to 95 percentile correlated best with berm migration. It was found that if the 75 percentile velocity exceeds 40 centimeters per second $(\mathrm{cm} / \mathrm{sec})$ or the 95 percentile exceeds $70 \mathrm{~cm} / \mathrm{sec}$, then the berm should be active.

The second way Hands and Allison (1991) determined whether a berm will be active or stable was to determine the response of the berm as a function of wave and sediment parameters. For this method, Hallermeier's Inner and Outer DOCs (Hallermeier 1981) were used to determine stability. The 11 berms were plotted on a chart (Figure 2) to compare depth of placement with the calculated Inner and Outer DOCs. It was determined that if the berms were placed shallower than Inner DOC, they were active. If placed deeper than the Outer DOC, the berms were found to be stable. There existed a buffer zone for stable berms where the material was placed 50\% shallower than the Outer DOC. 
Figure 2. Nearshore berm stability graph illustrating the difference between active and stable berms in deep or shallow water (from Beck et al. [2012], modified from Hands and Allison [1991]).

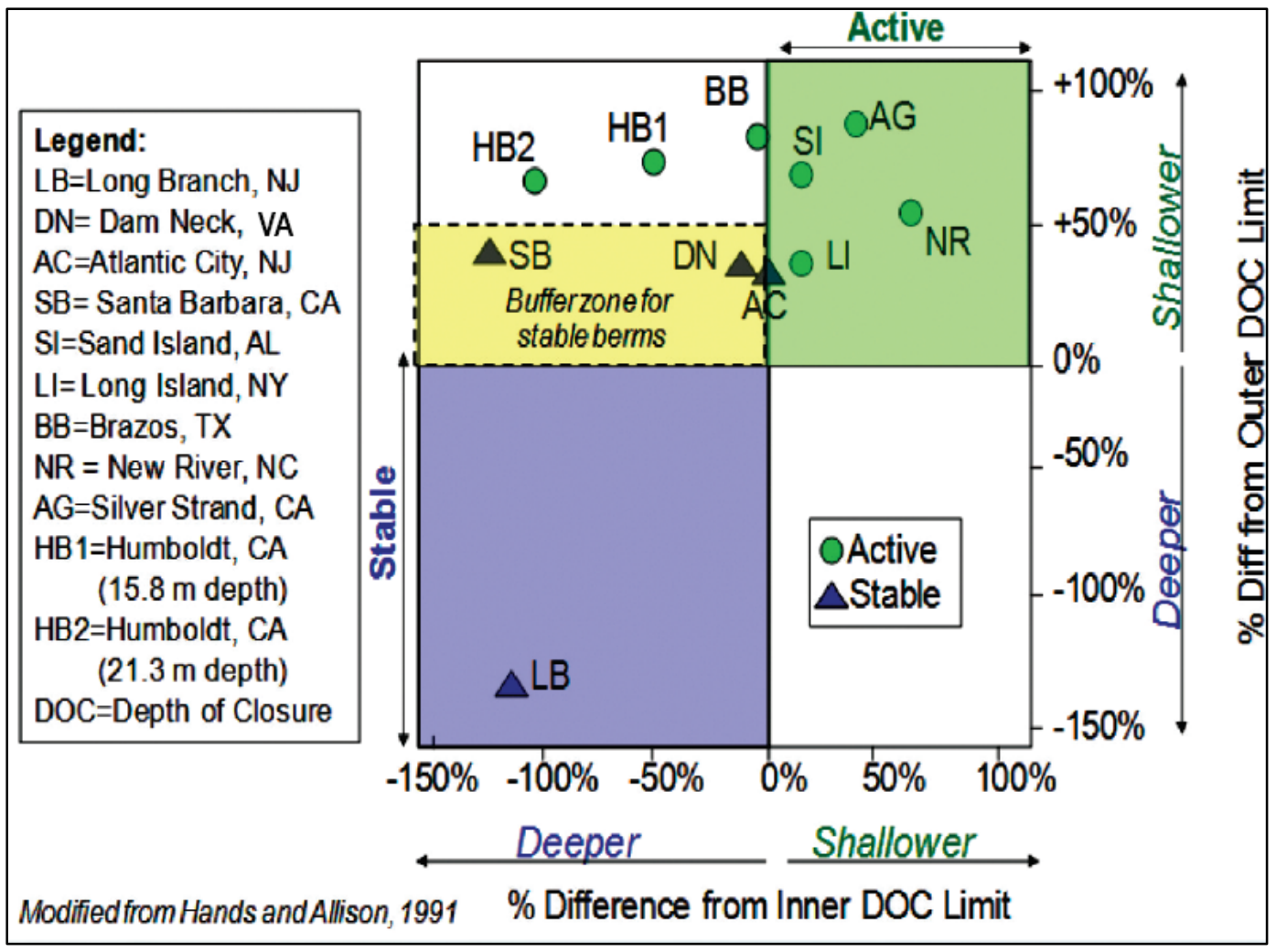

The Hands and Allison (1991) criteria have been broadly and successfully used to evaluate berm stability, as discussed in the following. However, Dean and Dalrymple (2002) pointed out that the well-documented 19891991 Perdido Key berm (discussed in more detail in the following section) was predicted to be active according to the Hands and Allison (1991) model, contrary to field results. The Perdido Key berm is not included in the Hands and Allison (1991) analyses (Figure 2). This may be because using the DOC as an indicator of mobility might lead to a conservative estimate of depth of mobility.

\subsubsection{Mobility predictions using morphologic and hydrodynamic parameters}

Assuming that bar-shaped nearshore berms should behave similarly to natural bars, Larson and Kraus $(1992,1994)$ investigated the morphodynamics of the longshore bars at the FRF in Duck, NC. They hypothesized nearshore berm behavior may be similar to nearshore bar behavior, particularly if the berm is placed as an elongated bar. The generally dissipative beach at Duck is characteristic of a two-bar system: 
an inner bar approximately 300 feet (ft) from the shoreline and an outer bar approximately $1000 \mathrm{ft}$ offshore and provided a good opportunity to study nearshore bar dynamics. Bi-weekly beach and nearshore profile surveys were conducted for 11 years totaling approximately 300 surveys that were used in the Larson and Kraus $(1992,1994)$ studies. Generally, a monotonic profile is often used to represent an equilibrium shape (Bruun 1954; Dean 1977 1991; Bodge 1992; Wang and Davis 1998, 1999). Larson and Kraus $(1992,1994)$ created a modified equilibrium profile for the FRF based on all of the survey lines by first averaging all of the profiles in the study area. Based on the average profile derived from the FRF data and the Dean (1977) equilibrium profile concept, the following equation was developed:

$$
h=A_{*}\left[x+\frac{1}{\lambda}\left(\frac{D_{0}}{D_{\infty}}-1\right)\left(1-e^{-\lambda x}\right)\right]^{2 / 3}
$$

where $h=$ water depth, $A_{*}=$ shape parameter based on median grain size, $x=$ distance offshore measured from the mean sea level shoreline, $D_{o}=$ equilibrium wave energy dissipation per unit volume in the inshore, $D_{\infty}=$ equilibrium wave energy dissipation per unit volume in the offshore, and $\lambda$ = characteristic decay length describing the rate at which $D_{o}$ reaches $D_{\infty}$. Based on Larson and Kraus (1992), $\lambda$ is determined empirically.

By comparing individual barred profiles with the monotonic equilibrium profile, Larson and Kraus (1994) made many observations on bar migration based on the relationships between different bar parameters and wave heights. They documented strong correlations between bar volume and bar height, bar volume and bar length, depth of bar crest, and distance to its center of mass. Furthermore, Larson and Kraus (1994) examined relationships between bar properties and incident wave conditions. Correlations were identified between certain wave properties and bar properties, including $h_{c} /\left(H_{o}\right)_{\max }$ and $\left(H_{o} / L_{o}\right)_{\text {mean }}$, and $\Delta V_{b} / H_{o}{ }^{2}$ and $\left(H_{o} / w T\right)_{\text {mean }}$, where $h_{c}$ is the water depth at the bar crest, $\left(H_{o}\right)_{\text {max }}$ is the maximum deep wave height, $\left(H_{o}\right)_{\text {mean }}$ is the mean deep water wave height, $\left(L_{o}\right)_{\text {mean }}$ is the mean deep water wave length, $\Delta V_{b}$ is the change in bar volume, $H_{o}$ is the deep water wave height, $w$ is the sediment settling velocity, and $T_{\text {mean }}$ is the mean wave period. Using the Dean Number, $H_{o} / w t$, Larson and Kraus (1992) estimated whether the bar would move on or offshore. If the Dean Number relationship were found to be greater 
than 7.2, bar migration would be offshore. If it were less than 7.2, bar migration would be onshore.

The findings determined through the study at the FRF field data were applied to a nearshore berm at Silver Strand, California (Larson and Kraus 1992). The authors found that the criteria determined from the FRF study successfully predicted the nearshore berm morphologic evolution at Silver Strand, California. Because of this, it was concluded that the geometric bar property correlations derived from the U.S. east coast (FRF) may apply to other coasts and to the morphodynamics of nearshore berms. Furthermore, these parameters may be used in the design of nearshore berms. More details on the Silver Strand nearshore berm will be described in Section 4.

\subsection{Other design and placement considerations}

In the 1990s, several USACE Dredging Research Program reports and papers were compiled describing general design guidance for nearshore placement. The following section summarizes those placement considerations.

McLellan (1990 a,b) stressed the importance of design in the placement of sediment in the nearshore, stating that the berm should be considered an engineered structure, requiring a design template that can be verified, construction methodology, and periodic maintenance throughout the design life of the structure. Based on several studies (Zwamborn et al. 1970; Frisch 1979; Gunyakt, 1987), McLellan suggested creating a linear berm as opposed to a conical berm to avoid wave focusing. It is also suggested that the orientation of the berm should be shore parallel to take advantage of wave energy reduction benefits.

McLellan et al. (1990) and subsequently McLellan and Kraus (1991) proposed comprehensive design guidance for nearshore berm construction. McLellan et al. (1990) summarized four steps to determine successful berm design and construction: (1) quantity and quality of material to be dredged, (2) availability of suitable equipment, (3) local wave conditions, and (4) economics of berm construction and alternatives. McLellan et al. (1990) and McLellan and Kraus (1991) suggested that artificial berm design should consider the following factors: (1) placement proximity to navigation channel, (2) timing of placement, (3) depth of placement, and (4) the overall dimensions (i.e., height, length, width, and 
side slopes) of the constructed berm to reduce potential wave focusing. In terms of location, they recommended that a feeder berm be placed downdrift of the inlet channel and away from the tidal inlet's hydrodynamic effects. The timing of the placement is also important. It is stated that for a beach with a typical winter-summer cycle in the northern hemisphere, the early- to mid-summer time frame should be optimal for accretionary wave conditions. If the placement is too close to the storm season, the material may move offshore. McLellan and Kraus (1991) state that the berm should be placed as close to the shore as possible within the constraints of safe navigation of the dredge to ensure optimum movement of material once it is placed. The dimensions of the berm are also an important design consideration. One of the key parameters is the length of the berm, which should be long enough to avoid wave focusing by wave refraction, and should depend on the hydrodynamic conditions (i.e., the wave height, period, and direction). The height of the berm has significant influence on the stability. It is stated that there was no explicit guidance on the width of the berm; however, wider berms allow for more waves to break along the crest. Side slopes of the berm are mainly a factor of grain size and sediment density, but the compaction of material, dredging and placement method, and currents during the placement also determine final slope (McLellan and Kraus 1991). At the time of their study, little information was available on the best side slope; however, there is mention of side slopes ranging from 1:100 to 1:30.

Burke and Allison (1992) used the Regional Coastal Process WAVE (RCPWAVE) model (Ebersole et al. 1986) to test berm slopes and potential wave focusing. Wave focusing may occur through wave refraction around the ends of nearshore berms or structures such as breakwaters that can lead to increased erosion on adjacent beaches (Dean and Dalrymple, 2002). They consistently used a $1 \mathrm{~V}$ on $25 \mathrm{H}$ inshore slope and a $1 \mathrm{~V}$ on $50 \mathrm{H}$ offshore slope but changed the end slopes of the berms as compared to crest lengths and various wave heights, hypothesizing that certain end slopes as compared to the crest length may cause wave focusing along the ends of the berms. It was determined that steeper end slopes cause end effects along a narrower region of beach; however, the milder slopes created less severe end effects. It was concluded that gentler slopes optimize berm design by reducing end effects. Slopes of $1 \mathrm{~V}$ on $125 \mathrm{H}$ and $1 \mathrm{~V}$ on $150 \mathrm{H}$ created the least amount of end effects. Using a slope of $1 \mathrm{~V}$ on $125 \mathrm{H}$, different berm crest lengths were compared, and it was determined 
that crests 610 meters $(\mathrm{m})(2,000 \mathrm{ft})$ or greater would not cause end effects from wave focusing.

Berm widths considerations were tested by Pollock and Allison (1993) to determine minimum berm widths for maximum wave height reduction benefits. Using the Numerical Model of the Longshore Current (NMLONG) (Kraus and Larson 1991), the study tested different berm widths and wave heights to determine the optimum berm width that attenuated the most waves. The study found that greater wave attenuation was achieved using greater berm crest widths. However, the rate of wave attenuation relative to berm crest width diminishes as the berm width increases. Steeper waves were affected more significantly by increases in berm width. It was found that significant wave height reduction in the lee of berm decreased once a berm crest reached $200 \mathrm{ft}$, therefore anything wider than that may not provide significant wave attenuation benefits.

Williams and Prickett (1998) summarized some of the planning considerations involved with placing dredged material in the nearshore. First, the two main types of dredges were discussed: mechanical versus hydraulic. It is stated that mechanical dredges lead to higher bulk densities of the material once it is placed, therefore likely causing the sediment to stay in the same place longer. Conversely, the hydraulic dredging process may lead to lower bulk densities, allowing material to disperse more quickly. Characteristics of the placement site are also important to consider. Bathymetry and hydrodynamics of the placement area determine how a nearshore berm will behave. Finally, economic considerations are important in determining how to place a nearshore berm. Mechanical dredges generally have a higher cost because they typically require tugs and support vessels to complete the placement process. Hopper dredges, a type of hydraulic dredge, can provide some cost savings since they are ocean going vessels that require less support. Additionally, if a hopper dredge is used, material placed in the nearshore will typically be closer to the borrow area, allowing for less cost in terms of transit time. 


\section{Modeling Studies of Nearshore Berms}

There have been many modeling studies, both numerical and physical, that have been conducted to better understand nearshore berms. Many of the numerical modeling studies use models to predict whether or not a berm will be active or stable based on hydrodynamic conditions of the area, grain size of the sediment, depth of placement, etc. Several studies use existing two- and three-dimensional (2D and 3D) numerical models that are validated using field data to understand more details of the impacts of the nearshore berm on the hydrodynamics of the region as well as to illustrate the morphological evolution of the berm. Physical models can provide insight to the sediment transportation processes occurring at the nearshore berm.

\subsection{Numerical modeling studies}

\subsubsection{Sediment Mobility Tool (SMT)}

The USACE CIRP and RSM Programs have collaborated to create the SMT, a scoping level tool to site nearshore berm placements based on predicted frequency of sediment mobility, dominant axis of wave direction, and onshore or offshore movement of the berm based on the Dean Number. The SMT is a web application that assists district engineers in preliminary assessments of potential nearshore placement sites. Rather than using the DOC, which may yield a conservative estimate of mobility, this method uses bed shear stress and near bottom velocity specific to a given location and grain size. (A more detailed summary of the SMT can be found in McFall et al. [2016]).

The tool uses WIS hindcast data that have been transformed to the specified nearshore placement site using Snell's Law and conservation of energy flux. Note that caution is advised when using this method inside of the surf zone, defined here as the cross-shore location of wave breaking, as the method does not incorporate the full effects on sediment mobility in this region. To determine frequency of sediment mobility, the SMT uses the transformed waves in two different methods. The first uses the maximum bed shear stress based on Linear Wave Theory to determine frequency of sediment mobility. The second uses the near-bottom critical velocity that is calculated using nonlinear, stream function wave theory. Frequency of sediment mobility is then summarized in histograms. 
Examples of histograms for both calculation methods from Duck, North Carolina, are shown in Figure 3 and Figure 4. The colored vertical dashed lines are the critical thresholds of mobility for each respective sediment grain size noted in the legend. The frequency sediment mobility and mean mobility index, $<\mathrm{M}>$, are noted in the legend.

Figure 3. Histogram of the calculated maximum bed shear stress at a depth of $8 \mathrm{~m}$ (from McFall et al. 2016).

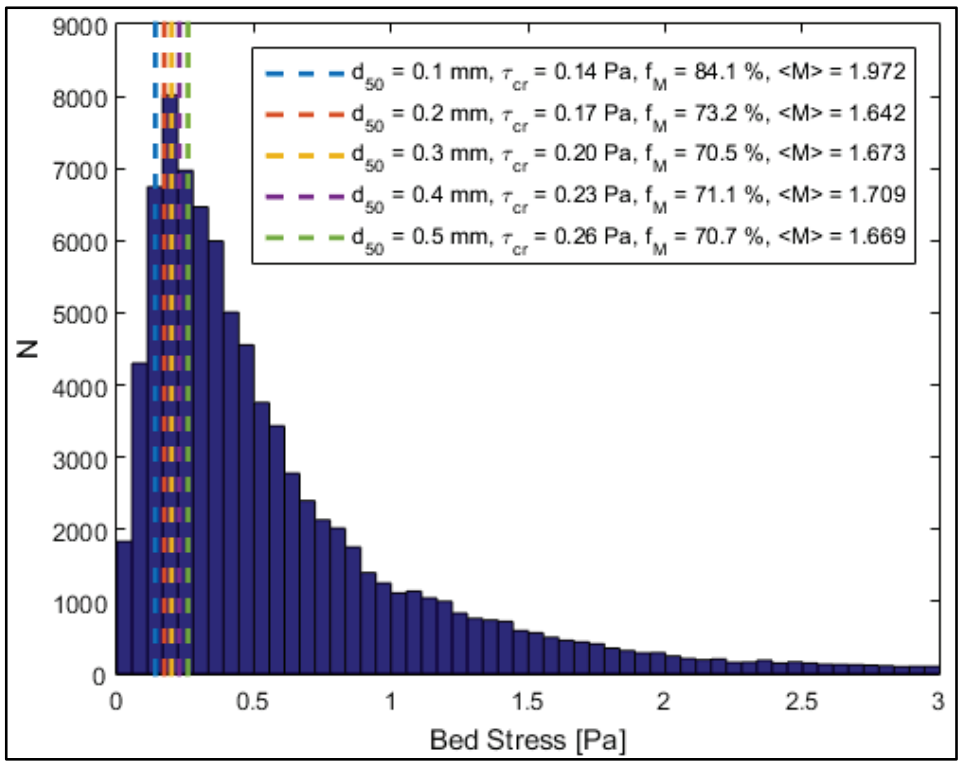

Figure 4. Histogram of the calculated near bottom velocity at a depth of $8 \mathrm{~m}$ (from McFall et al. 2016).

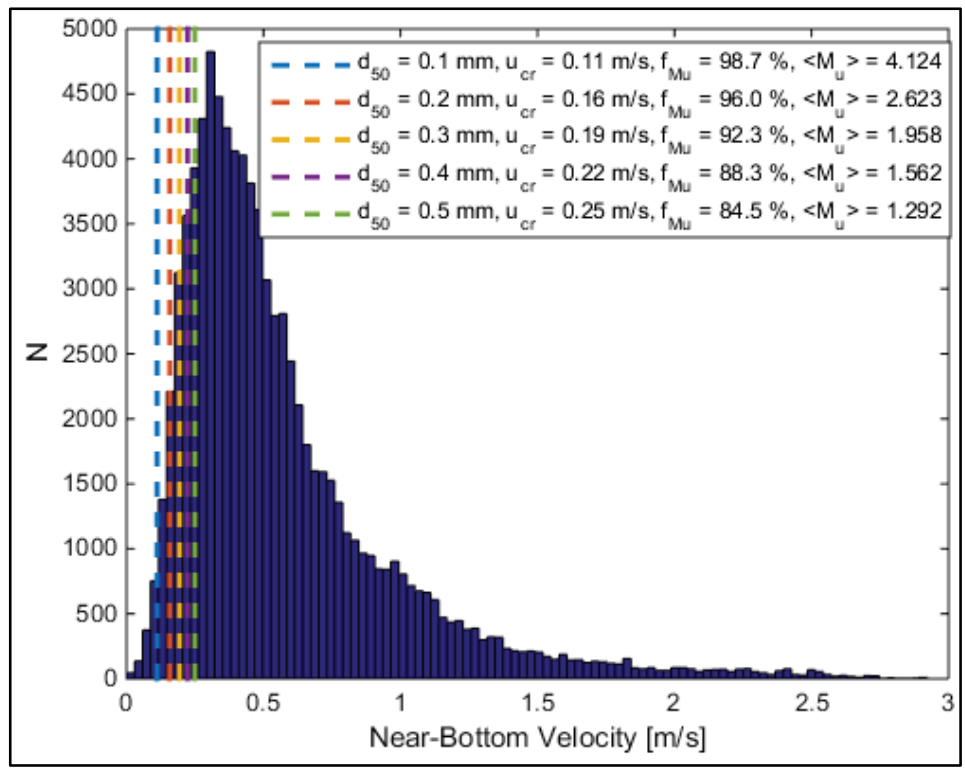


To determine onshore or offshore movement of the berm, the tool uses the Dean Number based on a study by Larson and Kraus (1992) as

$$
D=\frac{H_{0}}{\omega T}
$$

where $H_{o}$ is the offshore wave height, $\omega$ is the sediment fall speed, and $T$ is the wave period. Using data from the FRF, Larson and Kraus found that if $D$ were greater than 7.2, bar (or berm) migration would be offshore. If $D$ were less than 7.2, the bar would migrate onshore. The SMT also provides a wave rose of the transformed waves at the nearshore placement site with a resultant vector to provide an axis of wave-dominated sediment transport. In addition to the frequency of sediment mobility and general sediment transport direction calculations, the tool also calculates the DOC using Equations 1, 3, 4, and 5.

The SMT has been applied to several sites including Milford, Connecticut (McFall et al. 2015), Vilano Beach, Florida (Brutsché et al. 2017), and Duck, North Carolina (McFall et al, 2016). (The tool can be found online on the USACE Navigation Portal:

http://navigation.usace.army.mil/SEM/SedimentMobility.)

\subsubsection{Other predictive numerical models}

As is illustrated in the Chapter 2 Existing Design Guidance, hydrodynamic modeling, especially predictions of wave propagation, wave-induced currents, and wave dissipation, plays a crucial role in the evaluation of the design and anticipated performance of nearshore berms. As previously mentioned, Allison and Pollock (1993) examined the impacts of berm crest lengths and end slopes on wave propagation using the RCPWAVE. Berm crest widths were tested using the NMLONG. Recent developments in numerical modeling of coastal processes (e.g., Hanson and Kraus 2011; Larson et al. 2011; Lin et al. 2011, 2012; Reed et al. 2011) should provide valuable tools for improved design and evaluation of nearshore berms.

Scheffner (1991) proposed a systematic approach to analyze placement site stability, which includes numerical modeling of the wave field, storm surge, tidally driven currents, and magnitude of sediment transport using WIS data and Advanced Circulation (ADCIRC) modeling. Scheffner (1991) used equations by Ackers and White (1973) to create the transport model. The relationships predict sediment transport as a function of grain size, 
depth, and depth-averaged velocity. Because nearshore berms are placed in relatively shallow water depths, the equations were modified to increase the depth-averaged velocity. By applying this systematic approach to the Sand Island Mound near the entrance of Mobile Bay, Alabama, the author confirmed that the model accurately conveyed nearshore berm behavior.

Based on Bagnold's bed-load sand transport equation with Stokes' secondorder waver theory, Douglass $(1995,1996)$ developed an analytical model to calculate the landward migration rate of artificial berms. The model assumes that the onshore migration of the nearshore berm is driven primarily by the velocity asymmetry of finite-amplitude waves, an assumption that is commonly used to explain the onshore migration of nearshore bars (e.g., Larson and Kraus 1992). Convection and diffusion equations were used to describe the conservation of sand. The model uses the Bailard and Inman (1981) form of Bagnold's (1963) bed load transport model to calculate the rate of cross-shore sand transport. Given an estimate of the onshore-directed portion of the wave climate, the expected value of mound (berm) movement in any given depth $E[C(h)]$, can be estimated with $C$, the convection coefficient as follows:

$$
E[C(h)]=\iint p(H, T) C(H, T, h) d H d T
$$

With a tabular estimate of the joint probability of $H$ and $T$, Equation (8) can be simplified as

$$
E[C(h)]=\sum p(H, T) C(H, T, h)
$$

where the summation is across all $(H, T)$ bins and $p(H, T)$ is the probability of time that the wave height and period is of a specified magnitude. When applied to the Silver Strand nearshore berm, the model accurately depicted its rate of landward migration. Douglass $(1995,1996)$ indicated that the migration rate model is a very strong function of water depth where the active nearshore berm is placed. Based on the model, placement in $13 \%-16 \%$ shallower water depths would result in doubling the migration rate whereas doubling the water depth of placement will decrease the rate of migration by a factor of 16 to 32 .

Larson and Ebersole (1999) created an analytical model to predict the response of mounds offshore. The model employs a diffusion equation to describe mound response with respect to an equilibrium beach profile, 
where the diffusion coefficient is related to the local wave conditions at the mound. It provides quantitative information on how quickly a mound disperses under the influence of non-breaking waves at a particular site. The model was applied to berms in Silver Strand, California; Cocoa Beach, Florida; Maunganui Beach, New Zealand; and Perdido Key, Florida, to create an empirically derived expression for the diffusion coefficient and was validated for the four datasets. The model assumes that the transport in the offshore is a function of the onshore transport of sediment due to wave asymmetry and the offshore transport due to gravity. If, for example, the onshore transport due to wave asymmetry were larger than that due to gravity, the mound should move onshore. The diffusion equation created a way to describe the evolution of the mound in the offshore, and using nondimensionalized solutions, to determine the influence on wave height and water depth when considering two different mounds with the same shape.

\subsubsection{Other numerical model studies}

Previous studies describe analytical models that were utilized to predict mound migration and dispersion. Several studies have also used full-scale numerical models to illustrate mound migration. In these cases, extensive field studies were conducted to validate their models, and they were used to hindcast morphological evolution of the berm. The field studies will be described in the next section; however, the types of numerical models used will be briefly summarized here.

Pollock et al. (1998) used Storm Induced Beach Change Model Version 2.0 (SBEACH 2.0) and Long-Term Fate (LTFATE) models to analyze a nearshore berm placed in St. Johns County, Florida. The purpose was to predict the shoreline response to the presence of the nearshore berm. Stable and unstable berms were investigated as shore protection features for mitigation of coastal storm damage. SBEACH is a numerical simulation model for predicting beach, berm, and dune erosion due to storms (Larson and Kraus 1989; Larson et al. 1990; Rosati et al. 1993; USACE 1994). The model assumes that profile change caused by the storm is due to crossshore sediment transport processes. LTFATE is a $3 \mathrm{D}$-coupled hydrodynamic-sediment transport model that was developed to serve as a site-evaluation tool to estimate stability and dispersion of dredged material placed in open water (Scheffner et al. 1995). Results from the study showed that the nearshore berm should provide some level of protection against coastal storm damage to the adjacent shoreline due to waves breaking along the berm crest rather than the shoreline. 
An extensively studied nearshore berm in Terschelling, Netherlands, was modeled using UNIBEST (Hoekstra et al. 1996) and Delft3D (Grunnet et al. 2004). The nearshore berm was placed in 1993 and studied extensively for 2.5 years. Bathymetric surveys were frequently carried out, and hydrodynamic data were collected using a wave directional buoy for longterm data, as well as several process-oriented field measurement campaigns. Details of the morphological results of the study will be described in Section 4. The results of wave decay caused by breaking over the berm were described using the UNIBEST-TC model (Roelvink et al. 1996). UNIBEST-TC is a morphodynamic coastal profile model and was used to illustrate longshore sediment transport in addition to wave dissipation over the berm. It was determined through the use of that model that longshore sediment transport rates are important in understanding the behavior of the nourishment (Hoekstra et al. 1996).

The Delft3D modeling system is a fully 3D flow and sediment transport model applied in coastal environments (Grunnet et al. 2004). The model consists of Delft3D-FLOW and Delft3D-WAVE modules. Morphology is modeled using a morphodynamic feedback loop and consists of a number of integrated modules in which the wave and flow fields, sediment transport, and bed-level changes are computed sequentially (Grunnet et al. 2004). The model was applied to the Terschelling berm and calibrated using the full-scale hydrodynamic data that were previously mentioned. The model poorly predicted the measured results that the berm would flatten out; however, it did demonstrate skill in predicting the overall effects of the nourishment on adjacent shoreline dynamics. Over larger spatio-temporal scales, the model gives reasonable results of profile development and sedimentation at the shoreline, as well as onshore movement of the berm. However, detailed morphodynamic predictability was poor.

The same models were also used in hindcasting a nearshore berm placed offshore of Egmond aan Zee, The Netherlands (van Duin et al. 2004). A nearshore berm was placed at the location of the outer bar in the area and was combined with a beach nourishment. Bathymetric surveys were taken, and hydrodynamic data were provided by the Rijkswaterstaat and the Europport station. (More details regarding the results of the field component of this study will be summarized in Section 4.) UNIBEST-TC was found to be able to predict the shoreward bar movements and the detachment of the nearshore berm from the outer bar. Delft3D was used to 
determine the influence of the nearshore berm on the hydrodynamics in the region. The model showed decreased flow velocity at the shoreline and increased flow velocity at the nearshore berm due to wave breaking. The model also illustrated wave dissipation over the berm.

Kraiuciuniene et al. (2006) used the MIKE21 modeling suite (Danish Hydraulic Institute 2017) to illustrate the hydrodynamic and sediment processes associated with a nearshore berm off the Lithuanian coast in the Baltic Sea. MIKE21 is a 2D modeling system created by the Danish Hydraulic Institute. The modules used for this study include the NearShore Spectral Wind-Wave, Hydrodynamic, and the Sand Transport and were used to determine the best sites for nearshore berm nourishments of the Baltic Sea by analyzing sediment transport, bottom erosions, and dynamic equilibrium processes under varying climatic conditions, especially in stormy weather. The study ultimately found that the Melnrage II site is acceptable for nearshore berm nourishments. This site had been previously used, and the modeled results matched the actual results reasonably well. Similarly, the MIKE21 model was applied to a nearshore berm north of Torsminde, Denmark (Johnson et al. 2001). The model showed a rapid dissipation of wave energy and reduced wave heights in the lee of the berm. The estimates of the morphological change by the model reasonably match the actual morphological changes measured by bathymetric surveys.

Brutsché (2014) used the USACE-developed Coastal Modeling System (CMS) to illustrate the hydrodynamic influences of a nearshore berm placed in Fort Myers Beach, Florida. The CMS in an integrated 2D numerical modeling system for simulating waves, currents, water level, sediment transport and morphology change (Lin et al. 2008; Lin et al. 2011; Sánchez et al. 2011a,b; Sánchez et al. 2014). It consists of CMS-Wave and CMS-Flow that can be used in tandem through the steering module. At Fort Myers Beach, a nearshore berm was placed in 2009 and contained some gaps due to the placement techniques. Details of the morphologic evolution of the berm can be found in Section 4. Similar to the Delft3D model used for the Egmond aan Zee berm, the model showed that the strongest currents were found along the crest of the nearshore berm due to breaking (Figure 5). In the control areas, the strongest longshore currents were found at the shoreline. The model also illustrated the wave dissipation across the berm (Figure 5). Offshore-directed flow was captured in the gaps found along the berm. 
Figure 5. CMS modeling of the Fort Myers Beach nearshore berm illustrating $(A)$ wave dissipation across the berm, (B) longshore currents along the berm crest, and (C) flow through the gaps in the berm (from Brutsché 2014).

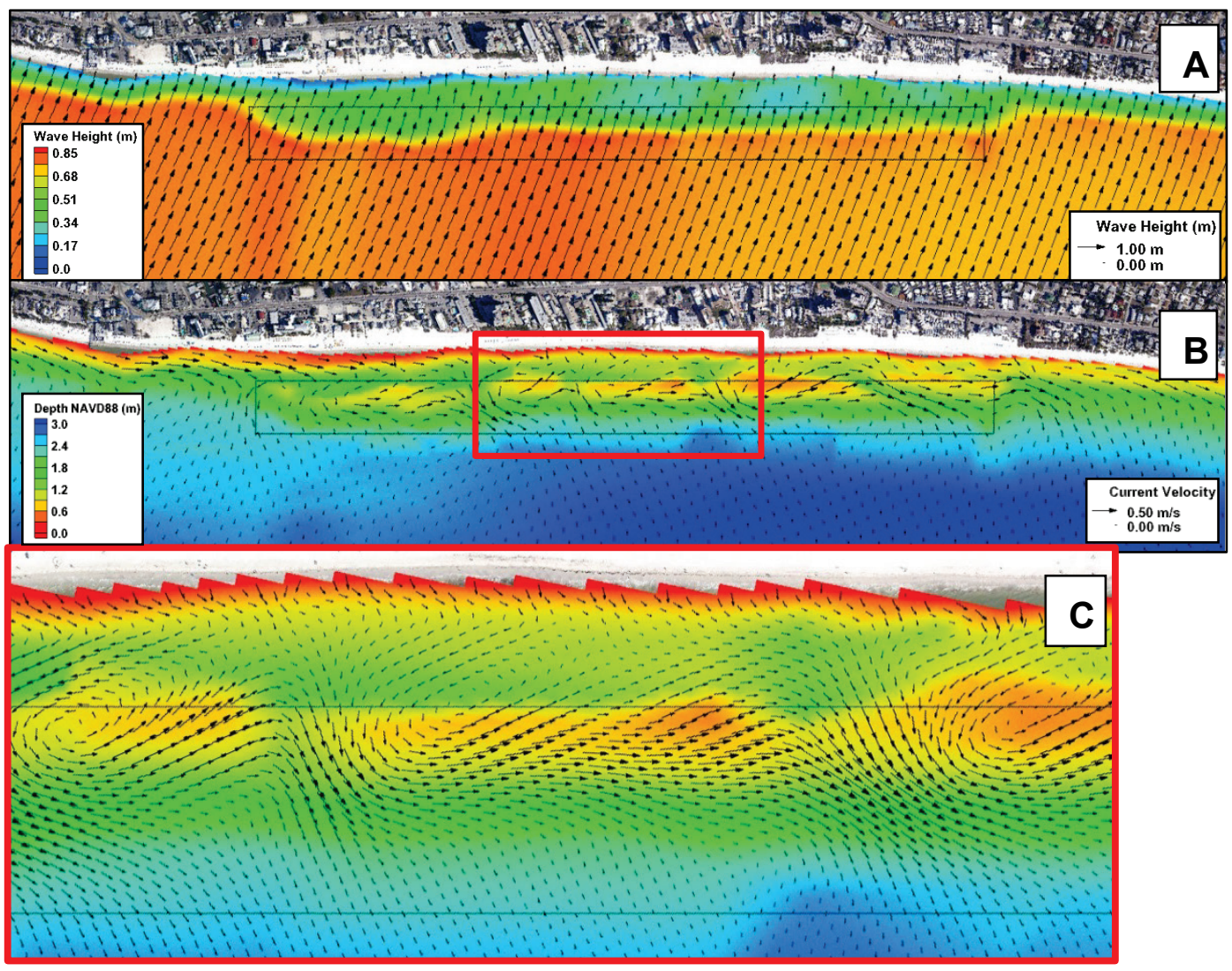

Gailani and Smith (2014) used several different numerical models to assess the optimal location of nearshore berm placement to be most beneficial to the adjacent shoreline along Tybee Island, Georgia. Currents were assessed using the ADCIRC model (Luettich et al. 1992), and waves were modeled using hindcast WIS data in the Steady-state Spectral Wave (STWave) model (Resio 1987, 1988; Smith et al. 2001). Finally, the General Transport (GTran) model (Gailani et al. 2003) was used to estimate sediment transport pathways. Sediment pathways shown in the GTran model were consistent with historic morphologic evolution, wave and current patterns, and dredging volumes and was therefore considered relevant for assessing the benefit of various placement options. Based on model results, the authors were able to recommend that the best location for nearshore berm placement would be adjacent to the transverse, shoreattached bar just offshore of central Tybee Island.

The Particle Tracking Model (PTM) was used in conjunction with a tracer study at Brunswick Harbor Entrance Channel, Georgia (Gailani et al. 
2007). Material is dredged from the channel and placed in several locations in the nearshore. (Results from the tracer study will be discussed in the next section.) PTM is a Lagrangian particle tracker that operates on user-specified, time-varying hydrodynamic conditions over the model domain generated by an Eularian hydrodynamic model (MacDonald et al. 2006; Gailani et al. 2007). PTM was used at the Brunswick Harbor Entrance Channel project and compared to a tracer study, and it was determined that PTM did well at predicting pathways and fate of silt-sized material released from the dredged material mounds. It was found that where 3D currents existed, PTM did not accurately replicate field measurements. This likely was related to the fact that the hydrodynamic model used in this particular study is $2 \mathrm{D}$ and cannot properly replicate $3 \mathrm{D}$ field measurements. The model is designed only to transport specified amounts of sediment sources and not the entire volume of sediment from the mound in order to make it more computationally efficient. The authors state that the limited range of sediment sources in PTM make the model perform poorly when attempting to simulate bedload transport in regions of evolving morphology, such as dredged material mounds, and this limitation should be considered when applying the model.

Lin et al. (2013) used the CMS, Short Term Fate (STFATE), and PTM models to evaluate potential nearshore placement sites in Noyo Harbor, California. The STFATE model (Johnson 1990) simulates the aerial distribution of dredged material in open water after it is passed through the water column on an individual release of the hopper or barge load. The simulations using the models included two placement sites. Simulations were conducted for combined tides, waves, currents, and wind forcing to evaluate the sediment transport at the placement sites. The study found that calculated morphology change due to the hydrodynamic forcing at the placement locations was insignificant as compared to changes observed in the nearshore due to the depths of the placement sites $(40-60 \mathrm{ft})$. The effects of placing the material at this location were determined to be insignificant compared to the existing configuration without the dredge material placement.

\subsection{Physical modeling studies}

\subsubsection{D models}

Zwamborn et al. (1970) conducted several tests modeling a submerged berm in 2D wave flumes ( 0.23 and $1.22 \mathrm{~m}$ wide) using fixed and movable 
beds to protect the nearshore berm placed along the Durban beaches in South Africa. The goal was to design a stable berm to dissipate energy from large, erosive waves and allow smaller high-frequency waves to pass unaffected. The model-to-prototype length scale was 1:100. The berm was modeled with sand $\left(\mathrm{d}_{50}=0.25\right.$ millimater $[\mathrm{mm}]$ and anthracite $\left(\mathrm{d}_{50}=\right.$ 0.190 and $0.27 \mathrm{~mm}$, specific gravity $(\mathrm{SG})=1.35$ ). In addition to scaling the model with Froude similarity, the shear-settling velocity similarity was also satisfied. The final berm design chosen was $1 \mathrm{~V}: 25 \mathrm{H}$ seaward and leeward slopes and $61 \mathrm{~m}$ (prototype) berm crest width. Results from the physical model were subsequently tested at the prototype scale with a $200 \mathrm{~m}$ long test section of the berm off the Durban beach. Model results were confirmed with a high degree of accuracy by the full-scale berm, and it was shown that an underwater mound of dredged material can offer an effective beach protection scheme.

Gunyakti (1987) conducted 2D experiments to study the effects of berm material and geometric shape on nearshore berm migration. The tests were conducted in approximately $12 \mathrm{~cm}$ of water. The berms were modeled with median grain sizes ( $\mathrm{d}_{50} \mathrm{O}$ ) ranging 0.23 to $0.4 \mathrm{~mm}$ with SG of 1.6 or o.34. Berms constructed of coarser material maintained its original volume in the berm site after the upper layers were transported to widen the berm. When the berm was constructed of fine and coarse non-cohesive sediment and placed between the natural breaking point and the point where the wave induced near-bed velocity was twice the critical limit, finer material was suspended and transported offshore while the coarser material was transported onshore. Berms constructed of fine and mediumsize sediment effectively nourished the beach. The results provide qualitative insight to the berm migration but may be contaminated by scaling effects.

The SUPERTANK large-scale laboratory collection project documented beach profile response to various wave and boundary conditions with high-density measurements of the waves and currents in the surf zone (Kraus et al. 1992). Experiments were conducted in the large wave flume (104 $\mathrm{m}$ long, $3.7 \mathrm{~m}$ wide, and $4.6 \mathrm{~m}$ deep) at the O.H. Hindsdale Wave Research Laboratory at Oregon State University with a flap-type wave maker. The beach was composed of $600 \mathrm{~m}^{3}$ of well-sorted fine sand with a median diameter of $0.22 \mathrm{~mm}$. Waves were measured at 26 cross-shore locations by resistance wave gauges, and the beach profile was measured in the center of the flume at the end of each wave-run segment with a 
Geodimeter T140 survey station. Wang and Kraus (2005) studied the beach profile equilibrium of six cases that had constant waves for at least 3 hours. Steep, irregular, erosive waves caused the shoreline to recede approximately $2 \mathrm{~m}$ and created a $30 \mathrm{~cm}$ tall sand bar. Smaller, irregular, accretionary waves had minimal impact on the shoreline but dispersed some of the sand bar's landward side in a thin layer between the bar and the shoreline. The bar height remained relatively constant, but the bar moved approximately $0.5 \mathrm{~m}$ offshore. Large regular, erosive waves caused the sand bar to migrate landward and created moderate erosion at the shoreline. Accretionary large waves caused the bar to move landward, and a slight advance of the shoreline occurred. Large bedforms or secondary bars were formed landward of the original bar. Erosional regular waves produced a steeper profile than the gentle profile with mid-surf zone secondary bars generated by the accretionary regular waves.

Holmes et al. (1996) studied the profile evolution of fine, coarse, and bimodal sand beaches in the large wave flume (6o $\mathrm{m}$ long, $3 \mathrm{~m}$ wide) at Imperial College using a working depth of $0.9 \mathrm{~m}$. Jonswap spectra with significant wave heights of 90, 70, and $45 \mathrm{~mm}$ were applied. Hydrodynamic data were collected using resistance wave gauges, laser Doppler anemometry, and acoustic Doppler velocimeter (ADV). The median grain size for the fine and course sand was $\mathrm{d}_{50}=0.5 \mathrm{~mm}$ and $\mathrm{d}_{50}=1.5 \mathrm{~mm}$, respectively. The bimodal sand beach was composed of a 50:50 mix of the fine and course sands. The fine sand beach tended to erode in the surf and swash zone, moving sediment to an offshore bar. The coarse sand beach transported onshore forming a berm above the still waterline. The beach profile of the bimodal mixed sediment behaved similarly to the fine sediment beach, but notable sorting occurred with fines moving offshore and coarse material depositing between the bar and the still waterline. Little evidence of armoring was observed in the highenergy conditions of this study.

Gravel, mixed gravel, and sand beach profiles were studied at the Grosser Wellenkanal-large wave channel (GWK) of Coastal Research Centre in Hannover by de San Román-Blanco et al. (2006). The GWK is $309 \mathrm{~m}$ long, $5 \mathrm{~m}$ wide, and $7 \mathrm{~m}$ deep. The gravel used for the beach had a diameter range of 16 to $32 \mathrm{~mm}$, with a mean diameter $\left(\mathrm{d}_{\mathrm{m}}\right)$ of $21 \mathrm{~mm}$. The mixed beach consisted of $70 \%$ gravel and $30 \%$ sand (sand: $\mathrm{dm}=0.3 \mathrm{~mm}$ ). The gravel beach had a porosity of 0.4 , and the mixed beach had a porosity of 0.2. The beach volume for both beaches was approximately $600 \mathrm{~m}^{3}$. 
Hydrodynamics were measured with 25 capacitance wave gauges, 24 pressure transducers, $3 \mathrm{ADVs}$, 1 hydrophone, and video recording to measure the wave runup. The profile is measured with three plastic rollers mounted on an arm attached to a mobile carriage. A representative gravel beach profile evolution of a gravel beach is given by de San Román-Blanco et al. (2006) showing a trough formation evolving in the surf zone and a bar formation above the still water level. With the exception of the representative beach profile evolution, minimal results and conclusions are made.

Çelikoğlu et al. (2006) studied the cross-shore sediment sorting under monochromatic wave action in a $24.5 \mathrm{~m}$ long, $5.4 \mathrm{~m}$ wide, and $1.0 \mathrm{~m}$ deep wave flume. Two sand sizes were tested with median grain sizes (d50) of 0.67 and $0.45 \mathrm{~mm}$. The mixed-sand planar beach had a slope of $1 \mathrm{~V}: 5 \mathrm{H}$ and a water depth at the wave maker of $0.7 \mathrm{~m}$. The fine material deposited on the bar crest and offshore. The coarse material deposited on the bar trough and foreshore regions. After sorting, armoring layers were established on both sides of the bar crest.

Guannel et al. (2007) used data from the 2005 CROss-Shore Sediment Transport Experiment (CROSSTEX) experiment in the $104 \mathrm{~m}$ long, $3.7 \mathrm{~m}$ wide, and $4.6 \mathrm{~m}$ deep wave flume at the O.H. Hindsdale Wave Research Laboratory to relate the movement of sand bars to the occurrence of wave breaking and magnitudes of undertow, velocity skewness, and acceleration skewness. The beach was created from sand sediment with a median grain size (d5o) of $0.22 \mathrm{~mm}$. Experiments showed undertow currents produced the first bar with offshore oriented transport. A second bar was formed with landward oriented transport with the first bar as the likely source of sediment.

Grasso et al. (2009) conducted a series of physical experiments using a lightweight sediment ( $\rho s=1.19$ kilograms per cubic meter) to apply Shields, Rouse, and Froude number scaling. Experiments were performed in a $36 \mathrm{~m}$ long and $0.55 \mathrm{~m}$ wide flume with a still water depth at the wave maker of $0.553 \mathrm{~m}$. It was found that the initial beach profile determined the time required for the profile to reach equilibrium but does not strongly influence the final shape. Wave climates with a Dean Number $(\mathrm{D}=$ $\mathrm{Hb}(\mathrm{wT}))$ of approximately 3.7 produced a steeper beach face accretion, and a value of 2.5 produced beach face erosion. The critical value for the Dean number was shown previous to this study as 3.2 (Dean and Dalrymple 
2002). Note that Kraus et al. (1991) found the critical Dean number to be 7.2 and validated this value with a nearshore berm in Silver Strand, California.

Hwung et al. (2010) conducted a series of nearshore berm experiments in a $25 \mathrm{~m}$ long, $30 \mathrm{~cm}$ wide, and $70 \mathrm{~cm}$ deep wave flume. The berm was modeled with artificial glass sand that had a median grain size $\mathrm{d}_{50}=0.32 \mathrm{~mm}$, porosity of 0.42 , and $\mathrm{SG}=2.45$. The berm was constructed on a fixed bed with bottom slopes of horizontal, $1 \mathrm{~V}: 60 \mathrm{H}, 1 \mathrm{~V}: 40 \mathrm{H}, 1 \mathrm{~V}: 20 \mathrm{H}$, and $1 \mathrm{~V}: 10 \mathrm{H}$. Sixtyeight trials were conducted with a water depth of $20 \mathrm{~cm}$. Scaling effects may affect the evolution of the bottom profile. It was determined that the berm migration was highly dependent on the local Shields number. For onshore migration, the optimal berm geometry has a berm height-to-water depth ratio greater than 0.8 , onshore berm migration dominates mild bottom slopes ( $1 \mathrm{~V}: 6 \mathrm{oH}$ to $1 \mathrm{~V}: 20 \mathrm{H}$ ), and offshore berm migration was prevalent with a steeper bottom slope (1V:10H).

Srisuwan et al. (2014) studied beach profile evolution using coarse, fine, and mixed sand sediment with three different initial beach profiles per sediment type in the wave flume facility of Karadeniz Technical University, Trabzon, Turkey. The wave flume dimensions were $32.5 \mathrm{~m}$ long, $1.4 \mathrm{~m}$ wide, and $1.2 \mathrm{~m}$ deep. Experiments were conducted in a water depth of $0.8 \mathrm{~m}$. The median grain size $\left(\mathrm{d}_{50}\right)$ for the fine, coarse, and mixed sand sediment was $0.18,0.363$, and $0.217 \mathrm{~mm}$, respectively. Hydrodynamics were measured with two capacitance wave gauges and one ADV. Sand samples were collected from the profile surface at the still waterline, bar trough, bar crest, and offshore portion of the sand bar structure. Erosive waves on the mixed sediment beach caused the bar to migrate offshore, and accretionary waves flattened the bar and moved it onshore. The initial beach profile had minimal influence on the equilibrium beach profile. Increased sediment mobility was observed in the mixed sediment beach compared to the coarse sand due to the influence of the fine sand. The size-specific sediment transport was evident due to the mean sediment size varying up to $20 \%$ along the cross-shore profile. The mean grain size remained generally constant at the shoreline, increased at the bar trough and bar crest, and decreased offshore of the bar. The fine material was transported offshore. 


\subsubsection{D models}

Vera-Cruz (1972) used a hydraulic model to study the artificial nourishment of Copacabana Beach, Brazil. The 3D model was built at a 1:30oHand 1:75V. Sand was represented by crushed bakelite, and the wave lengths applied were based on the vertical scale. No longshore littoral drift in the sediment was allowed in the model. A moveable bed was constructed, and waves were applied to the bed until equilibrium was reached. The artificial berm was constructed by dumping 4 liters of bakelite every 20 minutes at four locations along the prototype contour of $-5 \mathrm{~m}$. The model showed that offshore dumping of material was an efficient method of beach nourishment. The widening of Copacabana Beach validated the results of the hydraulic model, which agreed quite well.

Nearshore berms and sand bars have been physically modeled in the $3 \mathrm{D}$ Large-Scale Sediment Transport Facility (LSTF) at the ERDC in Vicksburg, MS. The LSTF is designed to simulate surf zone hydrodynamics and processes of a longshore beach in a finite-length basin. It consists of a $30 \mathrm{~m}$ wide, $50 \mathrm{~m}$ long, and $1.4 \mathrm{~m}$ deep basin and includes wave generators, recirculation system, sediment traps, and an instrumentation bridge. (Hamilton et al. [2001] describes the design considerations and capabilities of the LSTF in more detail.) The LSTF is shown in Figure 6.

Wang et al. (2003) studied the beach profile evolution under spilling and plunging breakers of similar height in the LSTF. A high wave height of $H_{m o}=0.45 \mathrm{~m}$ was run prior to the plunging waves, which developed a substantial offshore bar just outside of the surf zone. The bar migrated onshore during the reduced plunging wave height of $H_{m o}=0.27 \mathrm{~m}$. The bar migration resulted in elevation gain in the original bar's landward trough and elevation loss in the bar crest, eventually creating a small secondary bar landward of the original bar's trough. The newly developed secondary bar migrated seaward to merge with the original bar and return to the equilibrium single bar profile. The dynamic equilibrium of the bar/trough system is maintained by the balance between the onshore transport by the skewed wave's landward orbital velocity, and the offshore transport by the suspended sediment from the plunging jet and undertow. 
Figure 6. (A) Isometric view of the LSTF during a sediment transport experiment (Hamilton et al. 2001) and (B) plan view of the LSTF.

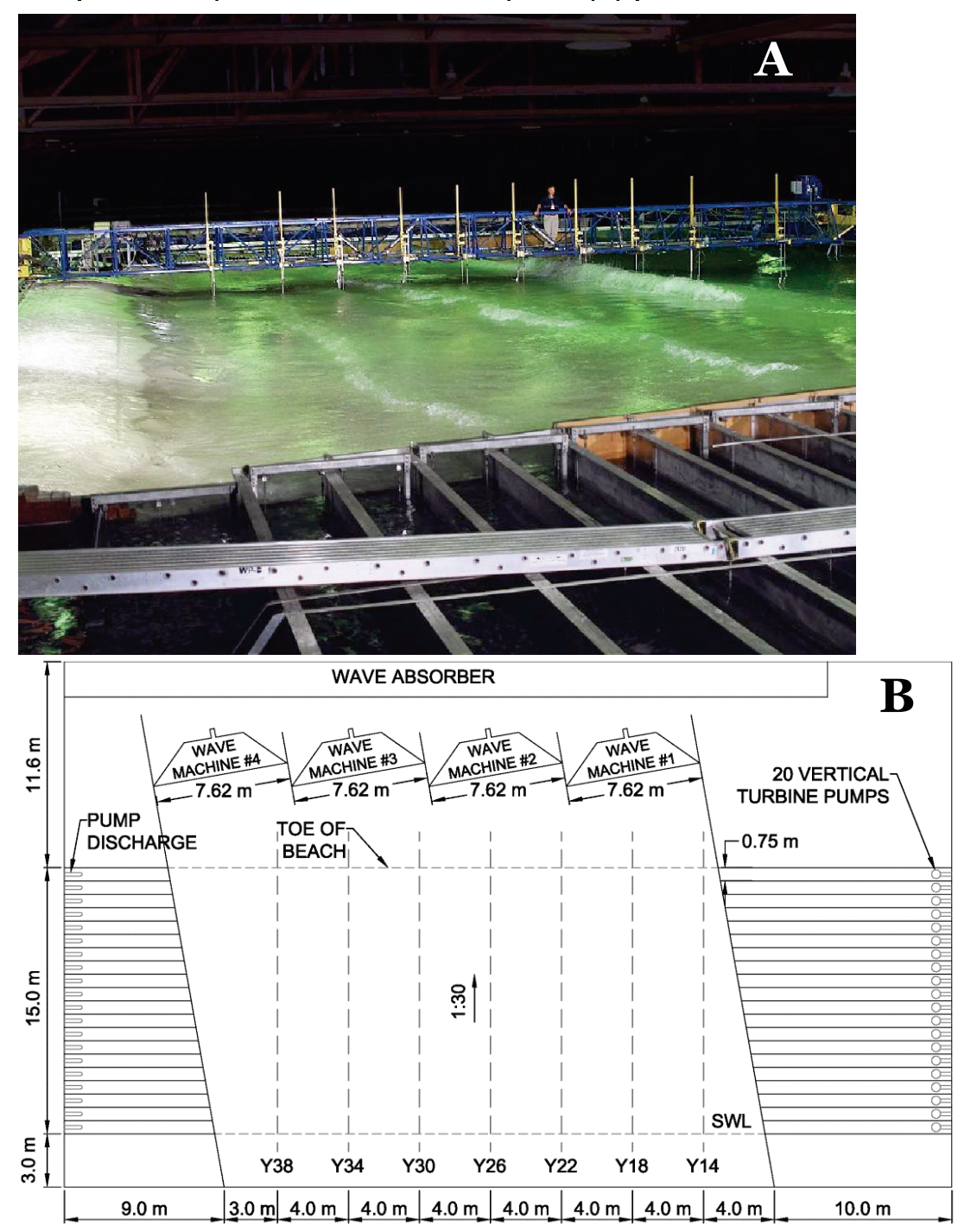

Smith et al. (2015) modeled two submerged nearshore berms and one subaerial berm in the LSTF. The two submerged nearshore berms modeled in Smith et al. (2015) had volumes of 0.1 and $0.17 \mathrm{~m}^{3}$ of finely sorted sand, respectively, with a median grain size, $\mathrm{d}_{50}$, of $0.15 \mathrm{~mm}$. The berms had lengths of 3 and $4 \mathrm{~m}$ and were placed in model water depths 0.17 and $0.06 \mathrm{~m}$ below the still water level, respectively. The subaerial berm had a volume of $0.21 \mathrm{~m}^{3}$ and a length of $4 \mathrm{~m}$. The berms were constructed on a $150 \mathrm{~m}^{3}$ sand beach with the same sand material as the berm. The TMA shallow-water wave spectrum applied to the berms had a peak period, $T p$, of $1.5 \mathrm{~s}$ and wave height, $\mathrm{Hmo}$, at the wave maker of $0.18 \mathrm{~m}$. These wave conditions translate to a $6.7 \mathrm{~s}, 3.6 \mathrm{~m}$ wave at a water depth of $18 \mathrm{~m}$ using a 1:20 model to prototype length scale. 
The results for the tested wave condition found that the sand in the berms stayed in the littoral system and migrated predominately downstream in the longshore current (Figure 7). No apparent onshore accretion of the submerged berms was observed, most likely to due to the erosive wave size applied. The shallow submerged berm was characterized by great crossshore dispersion and dramatic longshore transport (Johnson and Smith 2012). The beaches did accrete shoreward of the submerged berms, indicating that the berms altered wave and current conditions to deposit sand leeward of the berms, although not necessarily due to sediment coming from the berm placement itself. Recommendations for future tests include using smaller accretionary wave conditions, running the tests longer to investigate the beach response to the accreted sand due to the wave sheltering of the submerged berms, and investigating berm mixing with native material with cross-shore and longshore sediment cores.

Figure 7. Results from Smith et al. (2015) showing downstream migration of berms.

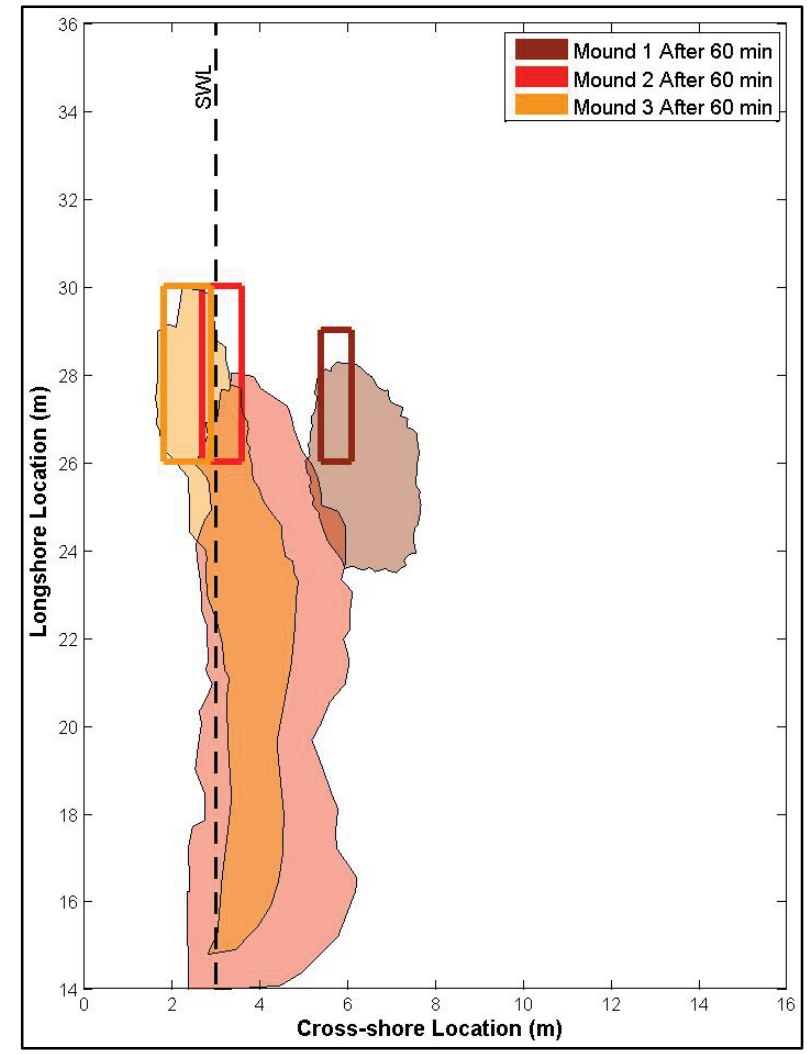




\section{Field Studies of Nearshore Berms}

Field studies are of the utmost importance in the understanding of nearshore berm placements as performance is influenced by site-specific hydrodynamic and morphologic conditions. Information on the morphological evolution of existing berms should provide insight on the practice of berm nourishment projects. Data collected in the field can be and have been used to validate and calibrate the previously described modeling studies. There have been many studies that have documented morphological evolution of these types of nourishments. A summary of many nearshore berms that have been placed since 1935 can be found in Table 1. Construction of submerged berms in the United States appears to have begun in the mid-1930s in Santa Barbara, California (Hall 1952). Interest in this type of nourishment and shore protection has increased in recent years. This section discusses many selected field studies on nearshore berms, many of which employ the previously discussed models and techniques to analyze their dynamics.

Table 1. Summary of existing artificial berms/mounds (Wang et al. 2013). A portion of this table was obtained from Otay (1994).

\begin{tabular}{|l|c|c|c|c|c|c|l|}
\hline Location & Year & $\begin{array}{c}\text { Placed } \\
\text { Volume X } \\
10^{3}\left(\mathrm{yd}^{3}\right)\end{array}$ & $\begin{array}{c}\text { Placement } \\
\text { Water } \\
\text { Depth (ft) }\end{array}$ & $\begin{array}{c}\text { Berm } \\
\text { Height (ft) }\end{array}$ & $\begin{array}{c}\text { Sediment } \\
\text { Grain Size } \\
(\mathrm{mm})\end{array}$ & $\begin{array}{l}\text { Stable or } \\
\text { Active }\end{array}$ & Reference \\
\hline Santa Barbara, CA & 1935 & 201 & 20 & 5.0 & 0.18 & stable & $\begin{array}{l}\text { Hall and Herron } \\
\text { (1950) }\end{array}$ \\
\hline Atlantic City, NJ & 1942 & 3,531 & $15-25$ & - & 0.32 & stable & $\begin{array}{l}\text { Hall and Herron } \\
\text { (1950) }\end{array}$ \\
\hline Long Beach, NJ & 1948 & 602 & 28 & 7.0 & 0.34 & stable & $\begin{array}{l}\text { Hall and Herron } \\
\text { (1950) }\end{array}$ \\
\hline $\begin{array}{l}\text { Durban, South } \\
\text { African }\end{array}$ & 1970 & 3,270 & $23-52$ & $0-27$ & both & $\begin{array}{l}\text { Zwamborn et al. } \\
\text { (1970) }\end{array}$ \\
\hline $\begin{array}{l}\text { Copacabana } \\
\text { Beach, Brazil }\end{array}$ & 1970 & 2,616 & $13-20$ & - & $0.4-0.5$ & Active & Vera-Cruz (1972) \\
\hline $\begin{array}{l}\text { Long Island Sound, } \\
\text { CT }\end{array}$ & 1974 & 1,530 & 60 & 30 & silt & stable & $\begin{array}{l}\text { Bokuniewicz et al. } \\
\text { (1977) }\end{array}$ \\
\hline Lake Erie, OH & 1975 & 24 & 56 & 1.2 & silt & stable & Danek et al. (1978) \\
\hline New River Inlet, NJ & 1976 & 35 & $6-13$ & Up to $6 \mathrm{~m}$ & 0.49 & active & $\begin{array}{l}\text { Schwartz and } \\
\text { Musialowski (1977) }\end{array}$ \\
\hline $\begin{array}{l}\text { Tauranga Bay, New } \\
\text { Zealand }\end{array}$ & 1976 & 2,616 & $36-56$ & 30 & $\begin{array}{l}\text { Fine to } \\
\text { coarse } \\
\text { sand }\end{array}$ & stable & Healy et al. (1991) \\
\hline
\end{tabular}




\begin{tabular}{|c|c|c|c|c|c|c|c|}
\hline Location & Year & $\begin{array}{c}\text { Placed } \\
\text { Volume X } \\
10^{3}\left(y d^{3}\right)\end{array}$ & $\begin{array}{l}\text { Placement } \\
\text { Water } \\
\text { Depth (ft) }\end{array}$ & $\begin{array}{l}\text { Berm } \\
\text { Height (ft) }\end{array}$ & $\begin{array}{l}\text { Sediment } \\
\text { Grain Size } \\
(\mathrm{mm})\end{array}$ & $\begin{array}{l}\text { Stable or } \\
\text { Active }\end{array}$ & Reference \\
\hline Dam Neck, VA & 1982 & 850 & $33-36$ & 11 & 0.08 & stable & $\begin{array}{l}\text { Hands and Deloach } \\
\text { (1984) }\end{array}$ \\
\hline Sand Island, AL & 1987 & 350 & 19 & $6-7$ & 0.22 & active & $\begin{array}{l}\text { Hands and Bradley } \\
\text { (1990) }\end{array}$ \\
\hline Fire Island, NY & 1987 & 458 & 16 & 6 & & & McLellan (1990a) \\
\hline Jones Inlet, NY & 1987 & 392 & 16 & 6 & & & McLellan (1990a) \\
\hline $\begin{array}{l}\text { Mobile, AL (outer } \\
\text { mound) }\end{array}$ & 1988 & 18,704 & $35-45$ & 22 & fine & stable & McLellan (1990a) \\
\hline Coos Bay, OR & 1988 & 5,232 & $66-85$ & $15-25$ & $0.25-0.3$ & dispersed & $\begin{array}{l}\text { Hartman et al. } \\
\text { (1991) }\end{array}$ \\
\hline Silver Strand, CA & 1988 & 148 & $15-18$ & 7 & 0.2 & active & Andrassy (1991) \\
\hline $\begin{array}{l}\text { Kira Beach, } \\
\text { Australia }\end{array}$ & 1988 & 1,962 & 23-33 & 6.6 & - & active & $\begin{array}{l}\text { Smith and Jackson } \\
\text { (1990) }\end{array}$ \\
\hline $\begin{array}{l}\text { South Padre Island, } \\
\text { TX }\end{array}$ & 1989 & 438 & 26 & $2-4.6$ & & active & Aidala et al., (1992) \\
\hline $\begin{array}{l}\text { Mt. Maunganui, } \\
\text { New Zealand }\end{array}$ & 1990 & 105 & $13-23$ & 6.6 & - & active & Foster et al. (1994) \\
\hline Perdido Key, FL & 1992 & 4,000 & $16-20$ & 5.7 & 0.3 & stable & Otay (1994) \\
\hline Port Canaveral, FL & 1992 & 130 & $17-22$ & 5.4 & & active & Bodge (1994) \\
\hline Port Canaveral, FL & 1993 & 200 & 22 to $>26$ & - & & $\begin{array}{l}\text { Both } \\
\text { stable } \\
\text { and } \\
\text { active }\end{array}$ & Bodge (1994) \\
\hline New Port Beach, CA & 1992 & 1,670 & $5-30$ & Up to 16 & $0.09-0.22$ & $\begin{array}{l}\text { Both } \\
\text { stable } \\
\text { and } \\
\text { active }\end{array}$ & Mesa (1996) \\
\hline $\begin{array}{l}\text { Terschelling, the } \\
\text { Netherlands }\end{array}$ & 1993 & 2,616 & $16-23$ & - & - & active & Kroon et al. (1994) \\
\hline $\begin{array}{l}\text { Egmond, the } \\
\text { Netherlands }\end{array}$ & 1999 & 1,177 & 25 & 2 & 0.2 & active & $\begin{array}{l}\text { Van Duin et al. } \\
\text { (2004) }\end{array}$ \\
\hline Ocean Beach, CA & 2005 & 902 & $30-46$ & & 0.18 & active & $\begin{array}{l}\text { Barnard et al. } \\
\text { (2008) }\end{array}$ \\
\hline Ft. Myers Beach, FL & 2009 & 229 & $5-8$ & Up to 6 & 0.17 & active & $\begin{array}{l}\text { Brutsché et al. } \\
\text { (2014) }\end{array}$ \\
\hline
\end{tabular}

Several nearshore berms were studied in the 1930s through the late 1940 s (Hall and Heron 1950; Hall 1952) located in Santa Barbara, California; Atlantic City, New Jersey; and Long Beach, New Jersey. These three berms were studied using hydrographic surveys and recording hydrodynamic data. 
Regarding the berm in Long Branch, New Jersey (placed at - $42 \mathrm{ft}$ mean low water [MLW]), over the 2-year study period, it was concluded that there was some accretion over the mound, but there was still extensive erosion along the shoreline, and therefore the material did not benefit the beach (Hall 1952). However, the author did state that perhaps during a longer period of observation the beach may gain some benefit, the method of placing material in the nearshore may not provide nourishment to the beach within a suitable time period. Both the berm in Santa Barbara, California (placed at the $-20 \mathrm{ft}$ mean lower low water [MLLW] contour) and Atlantic City, New Jersey (placed at the -18 to $-20 \mathrm{ft}$ MLW contour) behaved similarly.

Due to the undesirable outcome of the previously described three nearshore berms, the concept of placing material in the nearshore was largely abandoned until the late 1960 . As previously described in Section 3.2.1, Zwamborn et al. (1970) described a berm placed in Durban, South Africa. The nearshore berm was designed to be stable, placed at

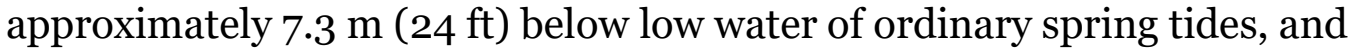
to be approximately 8 million $\mathrm{m}^{3}$ (10.5 million cubic yards [yd 3 ]). A physical model was run to determine whether or not the berm would be stable under those conditions (see Section 3.2.1). At the time of the Zwamborn et al. (1970) writing, approximately 2.5 million $\mathrm{m}^{3}$ (3.3 million $\mathrm{yd}^{3}$ ) of sediment had been placed and was virtually stable, but if losses did occur, the mound rebuilt itself. The nearshore berm did provide some protection for the leeward beach. During a storm that occurred in May 1966 , beaches that were in the lee of the berm experienced $8 \%-25 \%$ less erosion than those that were not.

McLellan et al. (1988) described a nearshore berm that was placed in Fire Island, New York. Material was dredged from Fire Island Inlet and placed in the nearshore in the summer of 1987. The berm was approximately $422,500 \mathrm{yd}^{3}$ and placed within the $16 \mathrm{ft}$ contour. The berm was split into three sections for the purposes of the study, and it was found that the steepness of the side slopes was a result of the placement technique and the relative depth. At deeper water sites, the noncohesive particles undergo discrete particle settling during the descent phase, allowing for greater spreading and gentler side slopes (McLellan et al. 1988). McLellan et al. (1988) concluded that it is important to have better tools to predict nearshore berm response to waves and currents to allow the designer to properly site the berm for maximum benefit and to provide an approach 
quantifying benefits. It is stated that field monitoring is essential to improve the data available to support these research needs.

A nearshore berm was placed at Sand Island, Alabama, in 1987, consisting of $464,000 \mathrm{yd} 3$ placed at approximately the $20 \mathrm{ft}$ MLLW contour (Hands and Bradley 1990). The study scheme included hydrodynamic measurements, bathymetric measurements, as well as seabed drifters and grab sediment samples. The Hands and Allison (1991) study showed survey data that indicated the mounds moved approximately $30 \mathrm{~m} / \mathrm{year}$ (98 ft/year) initially. Douglass (1996) used the previously mentioned numerical model (see Section 3.1.2) to show that it matched well when a calibration coefficient of $A=0.5$ was used. Hands and Bradley (1990) state that if the berm had been placed shallower, the material likely would have moved more rapidly.

Andrassy (1991) and Junhke et al. (1990) monitored the 1988 placement of a nearshore berm at Silver Strand State Park in California using material dredged from San Diego Harbor. The berm was approximately $1200 \mathrm{ft}$ long, $600 \mathrm{ft}$ wide, had an average relief of $7 \mathrm{ft}$; a total volume of approximately $150,000 \mathrm{yd}^{3}$ of fine sand was placed between the 15 and 28 $\mathrm{ft}$ depth contours, or above the depth of closure of $33 \mathrm{ft}$ for this area. Because it was built shallower than the depth of closure, the berm was expected to be active. During the first 2 years after the berm placement, Andrassy (1991) documented onshore migration of the berm and nourishment of littoral zone. Of all the cases reviewed here, this is the only one that documented considerable subaerial sand accumulation on the beach, within and above the intertidal zone, which lies between zero and $10 \mathrm{ft}$ above MLLW at the site. The accumulation was interpreted as the direct result of onshore migration of the berm, in addition to the hydraulic effects (modification to wave propagation pattern) of the berm. Long period summer swells may have provided favorable accretionary wave conditions. The Silver Strand case has been used by several previously described modeling studies (see section 3.1) including (1) Hands and Allison (1991) for the development of the criteria to predict stable or active berm, (2) Larson and Kraus (1992) to verify the bar migration model, and (3) Douglass (1996) for predicting the onshore migration rate.

Aidala et al. (1992) studied a nearshore berm placed at South Padre Island, Texas, to determine the correlations between a nearshore feeder (or active) berm and hydrodynamic forcing. Methods included conducting 
hydrographic surveys, collecting sediment samples, taking wind measurements, using wave hindcasts, and conducting seabed drifter studies. Hydrodynamic parameters influencing the direction of berm movement could not be concluded; however, results of the study indicated that both movement and erosion of the berm are influenced by the correlation between shear stress, threshold velocity, and bottom current velocity. It was concluded that when shear stress exceeds the threshold velocity, the berm will migrate. The bottom current then influences the course of the evolution.

A relatively large nearshore berm was placed offshore of Perdido Key, Florida, in 1989. The berm was built in conjunction with a beach nourishment. The Perdido Key berm was probably one of the largest and most comprehensively studied projects as it was monitored over an 8-year period including proximal passages of several hurricanes (Dean et al. 1995; Otay 1995; Work and Otay 1996; Browder and Dean 2000). Otay (1994, 1995) analyzed the berm nourishment based on topographic and bathymetric surveys, wave and current measurements, sediment sampling, meteorological data analysis, and analysis of oblique aerial photography. It was concluded that the berm remained largely stable with no significant volumetric changes with the exception of some degree of bathymetry smoothing (Otay 1995). Wave modeling completed by Work and Otay (1996) indicated that the berm provided some protection to the beach nourishment landward of the berm, which was also indicated by the bathymetric surveys showing that $84 \%$ of the beach nourishment remained after being placed 3 years prior. They concluded that this could be because the presence of the nearshore berm allows wave energy to be distributed differently or may allow more dissipation of wave energy, thus reducing wave energy reaching the shoreline. Browder and Dean (2000) analyzed additional longer-term survey data and concluded that 8 years after the construction, the berm remained largely stable with most of the placed sediment volume accounted for, confirming the earlier findings of Otay (1995). Eight years after the two nourishments were placed, $41 \%$ of the beach nourishment still remained. Based on the findings of Otay (1995) and Browder and Dean (2000), the Perdido Key berm behaved quite differently from most of the berms listed in Table 1. The Hands and Allison (1991) model would predict this berm to be an active one whereas the long-term field monitoring suggested otherwise. No specific reasons were given in any of the literature as to why the berm did not behave as expected. 
Maintenance dredging of Canaveral Harbor in 1992 and 1993 resulted in a nearshore berm disposal in Port Canaveral, Florida, offshore of Cocoa Beach. Bodge (1994) evaluated the performance of the berm based on time-series survey and sediment data. The study found that the most rapid onshore movement of the berm happened within days to a few weeks after the placement. Initial movement was approximately $100 \mathrm{ft}$ landward over the first 1- to 6-week period, and the height of the berm reduced correspondingly as it dispersed landward. After the rapid initial adjustment, the profile seemed to have approached equilibration as the rate of onshore migration was much slower over the next 10 months. Bodge (1994) applied the criteria to predict the behavior of the 1993 Port Canaveral berm and concluded that Hands and Allison (1991) model successfully predicted, as confirmed by field data, the shallow portion of the berm as being active and the deeper portion as stable. This study also found that there was little to no offshore movement, and negligible longshore spreading, of the material at this site.

A nearshore berm was placed in Newport Beach, California, in 1992. Mesa (1996) applied the Hands and Allison (1991) criteria to the berm in California and concluded that the berm could be considered both stable and active due to the fact that the depth of the berm as related to the Hallermeier Inner and Outer DOCs places the berm in the "buffer zone" in the Hands and Allison (1991) classification (Figure 2). Mesa (1996) suggested that the berm may be considered "weakly active" based on the fact that its position is only slightly greater than the $50 \%$ outer limit. Bathymetry measurements indicated that the berm was eroding by the dispersal of material from the berm crest shoreward while the base remained stable. Overall, the berm migrated shoreward at a rate of approximately $100 \mathrm{ft} /$ year, with little indication that the berm moved alongshore. Additionally, Mesa (1996) suggested that the berm seemed to have improved the surfing conditions in the area, providing a positive public perception to local stakeholders. Mesa (1996) indicated that coarser sediments remained in the active littoral system and that the berm did not adversely affect the percentage of fines.

Kroon et al. (1994), Hoekstra et al. (1996), Grunnet et al. (2004), and van Duin et al. (2004) examined two shoreface nourishment (i.e., nearshore berm) projects conducted in the Netherlands using field methods and numerical modeling techniques. The numerical modeling aspects of the studies were described in Section 3.1.3. The field component of the studies 
will be described here. The project areas were characteristic of a dynamic 2bar system, and berms were placed in the vicinity of the bars. The Terschelling shoreface nourishment was placed in the trough between the two bars at a depth of 16 to $23 \mathrm{ft}$ below mean sea level (Kroon et al. 1994). The Egmond shoreface nourishment was placed directly seaward of the outer bar at a water depth of approximately $25 \mathrm{ft}$ (van Duin et al. 2004). Onshore migration of the nourishment material was measured for both cases. At both sites, the bar system was rapidly re-established following the placement, despite the different placement locations, leading both studies to the conclusion that the nearshore profile has the ability to rapidly restore its equilibrium shape against perturbations at this scale (van Duin et al. 2004; Kroon et al. 1994; Hoeskstra et al. 1996; Gruunet et al. 2004). Although the 2-barred profile was restored rather rapidly and maintained after the shoreface nourishment, the different placement locations resulted in differing initial morphological response. At Terschelling, the fill between the inner and outer bars induced onshore migration and upward growth of the inner bar while the elevation of the outer bar and the trough decreased. At Egmond, the shoreface nourishment seaward of the outer bar initiated a substantial shoreward migration of both bars during the first 2 years. A trough formed between the nourishment and the original outer bar, creating a 3-bar morphology (van Duin et al. 2004). However, during the third year, the system returned to the 2-bar shape. The exact cause of the return to the 2-bar profile was not explained other than nature's ability to return to its equilibrium state (van Duin et al. 2004). Van Duin et al. (2004) found that the shoreface nourishment had significant influences on the morphodynamics of the two natural bars. Each of these studies emphasized the functionality of the nearshore berm to operate as a submerged breakwater, influencing the nearshore wave propagation patterns and subsequently the shoreline configuration directly landward of the berm.

The USACE regularly dredges the Brunswick Harbor Entrance Channel in Georgia and places the material in several different locations in the nearshore. Several studies have been completed on the different placement locations (Johnson and Work 2005; Smith et al. 2007; Gailani et al. 2007). Johnson and Work (2005) specifically studied nearshore placement Site C in a field study conducted in 2003 and also conducted a predictive study based on several different sediment transport equations including Nielsen (1992), Van Rijn (1984a,b), and Soulsby (1997). The Nielsen and Soulsby approaches included the effects of waves gave similar results to the measured data. Results indicate that the channel steers the 
flow of water and sediments and that placing the material father downdrift of the entrance channel might increase the likelihood of indirect nourishment of the downdrift beaches. Smith et al. (2007) used fluorescent sediment tracers to evaluate the nearshore placement of dredged material along this portion of the coast of Georgia. Difficulties arose attempting to make quantifiable conclusions regarding the sediment tracers; however, several important qualitative assessments were noted: (1) fine sediments were found to winnow rapidly from the dredged material, (2) fine sediments were not found to deposit permanently in the inner shelf environment; rather the silt tracers that were found in isolated surface grab samples in the nearshore environment were not found in subsequent surveys, and, (3) sandy sediments were found to transport much shorter distances than that of the fine sediments and remained in the shallow nearshore environment. These data were also used to compare to the PTM, as discussed in section 3.1.3.

A nearshore berm placed at Ocean Beach, San Francisco, between 2005 and 2007 has been extensively documented (Barnard et al. 2006, 2007, 2008, 2009). Compared to many of the previously discussed berms, this location experiences relatively higher wave energy. Material was placed offshore of a known erosional hot spot along the California coast. The intent of the placement was to provide a buffer to an area of the coast that suffers erosion through wave attack during the energetic winter months. Although the beach response was inconclusive, bathymetric surveys

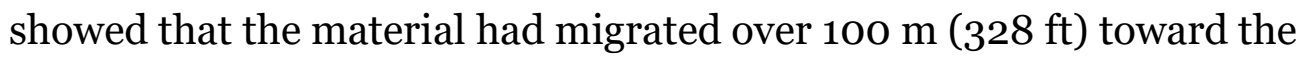
shoreline indicating that the placement is likely beneficial over the long term providing (1) additional wave dissipation during storms, (2) compatible sediment to feed the nearshore bars (3) sediment cover on an exposed sewage outfall pipe, and, (4) a viable alternative to the shoaling offshore disposal site (Barnard et al. 2006).

In New Zealand, a nearshore berm was placed along a rocky, high energy stretch of coast (McComb and Black 2001) and studied over an 18-month period. Results from the field study showed that there was a spatially uniform pattern of erosion, with rates related to wave height to the third power. In the survey area, uniform dispersal of the sand was observed resulting in smoothing of the isobaths over time. The data also suggested that sediment transport to and from the placement area was largely due to suspended load transport rather than bedload. No direct relationship between mound erosion and the current regimen was found. 
In 2009, a nearshore berm was placed in Fort Myers Beach, Florida, and was extensively studied and documented (Brutsché 2011; Brutsché and Wang 2012; Wang et al. 2013; Brutsché 2014; Brutsché et al. 2014). Material was dredged from nearby Matanzas Pass and placed in the nearshore northwest part of the island. The placement consisted of up to $16 \%$ fine material and could therefore not be placed directly onto the beach due to state regulations. Initially, the fine material was located in the trough landward of the berm; however, that material migrated offshore. The overall grain size of the dry beach remained relatively consistent throughout the study period, indicating that the fine material did not migrate onshore. Throughout the entire 4-year study period, the berm migrated onshore until it eventually reached a dynamic equilibrium state. By creating an average profile for the study area and calculating the variance of each profile from the average profile, it was determined that the two tropical systems that passed the study area in 2012 accelerated the equilibration process (Figure 8 ). The dry beach gained approximately $23,000 \mathrm{yd}^{3}$ of sediment due to the presence of the berm (Figure 9). The profiles immediately adjacent to the berm to the south also gained sand, indicating that the berm did not appear to have a negative impact to the adjacent beach as submerged breakwaters tend to do.

Figure 8. Average variance from the average profile of the study area (Brutsché et al. 2014; Brutsché 2014).

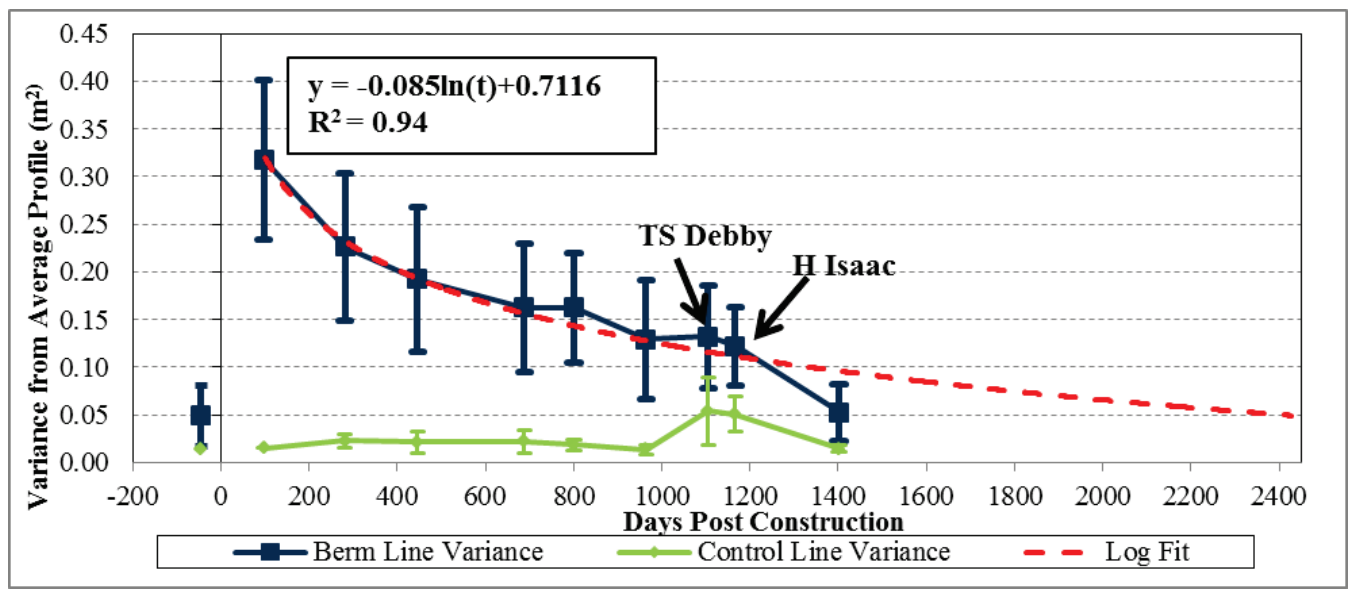


Figure 9. Dry beach width and volume change between April 2010 and May 2013 (Brutsché et al. 2014; Brutsché 2014).

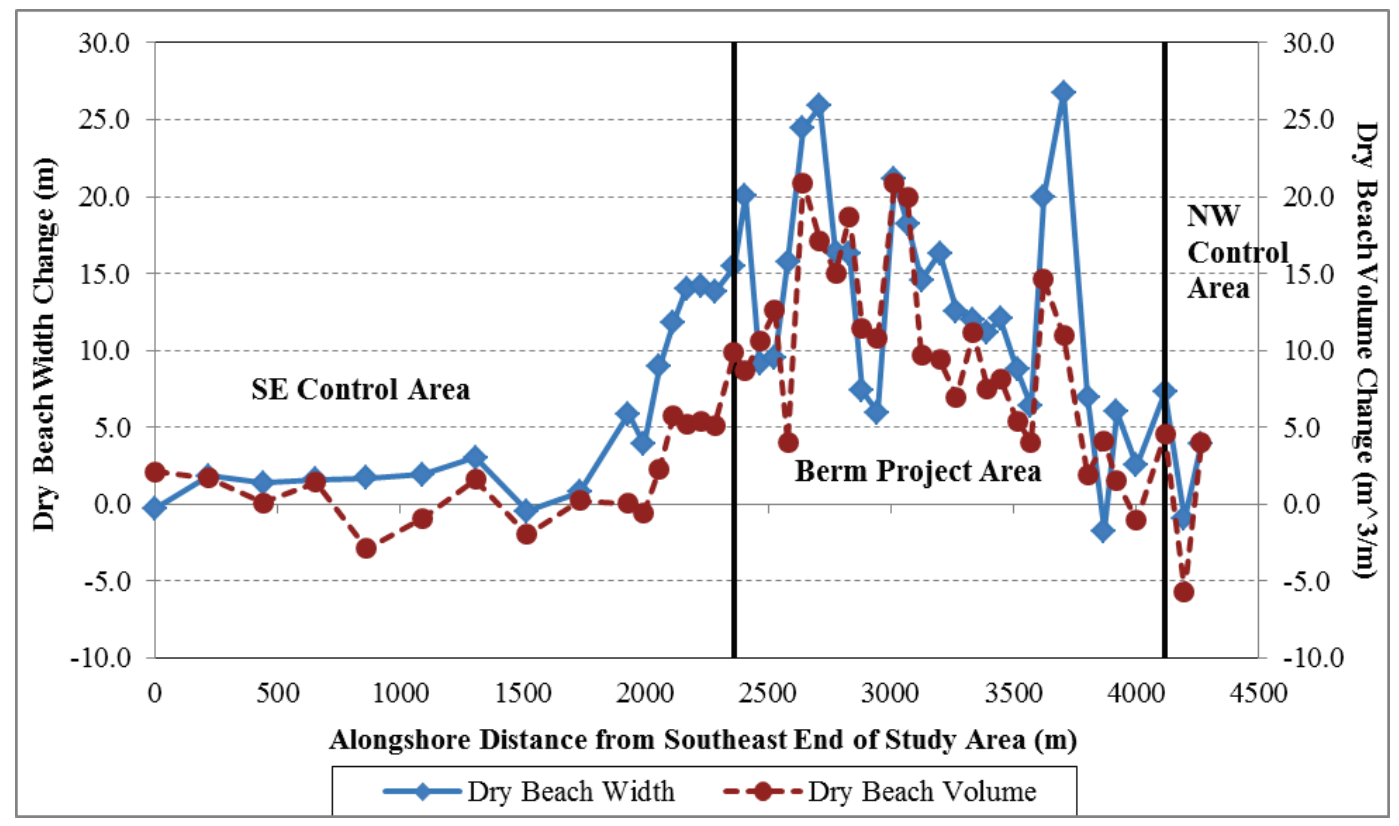




\section{Summary and Future Work}

It is important to have a better understanding of nearshore berm placements as they are becoming an increasingly utilized beneficial use method for dredged material. Design guidance exists to determine whether a nearshore berm will be active or stable based on DOC, as well as near-bed velocities. Additionally, guidance of nearshore placement shape in terms of berm crest width, height, and length has been well documented through USACE Dredging Research Program technical reports.

Many numerical and physical modeling studies have been completed to determine the fate of the material placed in the nearshore. Numerical models exist both to predict what will happen once the material is placed, as well as determine in greater detail the morphological evolution and hydrodynamic effects the berm has on the area. 2D and $3 \mathrm{D}$ physical models have also been employed to understand these concepts.

Field studies have shown that onshore migration and/or integration into the beach profile with alongshore dispersion usually occurs for active nearshore berms along the open coast, especially directly following placement. The function of shallow nearshore berms as submerged breakwaters is also well documented through numerical wave modeling.

Although many modeling and field studies have been conducted to assess morphologic and sedimentologic evolution of nearshore berms, a need still exists to fully understand the behavior of these types of nourishments. The overarching research goal is to build tools to predict where the material is going, how the existing beach/marsh responds to the placement, and how long the material will remain in place or its intended location. These goals can be further expanded to include details that are unique to a certain type of placement or location.

The landward limits of sediment migration are an important consideration, often the primary design parameter. The question of where the berm material will go can be divided into both sand and mixed berms, those containing or composed of fine material. Sand berms are covered in depth in the previous chapters, but mixed berms lack field observations. Often there are concerns over sediment from the berms covering nearby resources such as hard bottom habitat and cultural resources. Additionally, most of the physical model studies summarized here only consider cross-shore sediment transport (Zwamborn et al. 1970; Gunyakti 
1987; Kraus et al. 1992; Guannel et al. 2007; Grasso et al. 2009; Hwung et al. 2010), with little emphasis on the alongshore component of transport except for Vera-Cruz (1972) and Smith et al. (2014).

Measuring the transport of sediment in the field includes a host of challenges that drive the need for better measurement methods. Including high temporal and spatial fidelity hydrodynamics measurements of the nearshore especially during high energy events is paramount in developing tools to predict the berm transport. Douglass et al. (1995) notes the difficulties in measuring and correlating field measurements at a placement site with observed berm transport trends. Many of the studies detailed in this report did not measure both local waves and currents during berm monitoring. The local perturbation of the wave field and currents due to a berm placement are important to understand and include in engineering placement site design. Measurements comparing the hydrodynamics of an area with and without a nearshore berm are not often reported unless the goal of the berm is to act as a submerged breakwater (Zwamborn et al. 1970), did not perform as expected (Hall 1952), or is included in a multi-year monitoring effort (Van Duin et al. 2004; Brutsché et al. 2014). These measurements could help to develop guidance on the design of berms.

While monitoring the berm transport via bathymetric surveys has proven to provide considerable insight as detailed in the field studies chapter (Chapter 4), there still exists a need for more detailed measurements, both hydrodynamic and sedimentologic. Mapping berm geometric changes cannot answer questions related to sediment mixing, armoring or original mass content. Additionally, fine sediment can transport great distances and distribute over large areas reducing the value of bathymetric surveys. Improved low-cost tracers in conjunction with PTM or specially designed physical models could greatly aid in building and validating predictive tools.

The varying nature of wave energy results in intermittent transport constraining design and predictive tools to be based on statistical return periods. The SMT (McFall et al. 2016) is an example of this approach. This further reinforces the need for local, high temporal and spatial sampling of the hydrodynamics, berm geometry, and berm sedimentary characteristics. The research gaps overviewed here are not entirely unique to nearshore berm transport and could aid in a better understanding and prediction of the nearshore environment. 


\section{References}

Ackers, P., and R. W. White. 1973. Sediment transport: New approach and analysis. Journal of the Hydraulics Division, ASCE 99: 2041-2060.

Aidala, J. A., C. E. Burke, and T. N. McLellan. 1992. Hydrodynamic forces and evolution of a nearshore berm at South Padre Island, Texas. Proceedings Hydraulic Engineering '92, American Society of Civil Engineers, 1234-1239.

Allison, M. C., and C. B. Pollock. 1993. Nearshore berms: An evaluation of prototype designs. Coastal Zone '93, ASCE, 2938-2950.

Andrassy, C. J. 1991. Monitoring of a nearshore disposal mound at Silver Strand State Park. Proceedings Coastal Sediments '91, American Society of Civil Engineers, 1970-1984.

Bagnold, R. A. 1963. Mechanics of marine sedimentation. The Sea, Vol. 3. New York, NY: Interscience.

Bailard, J. A., and D. L. Inman. 1981. An energetics bedload model for a plane sloping beach: Local transport. Journal of Geophysical Research 86(C3): 2035-2043.

Barnard, P. L., L. E. Erikson, and J. E. Hansen. 2009. Monitoring and modeling shoreline response due to shoreface nourishment on a high-energy coast. In Proceedings of the 1oth International Coastal Symposium, Lisbon, Portugal. Journal of Coastal Research 1(Special Issue 56): 29-35.

Barnard, P. L., L. H. Erikson, J. E. Hansen, and E. Elias. 2008. The Performance of Nearshore Dredge Disposal at Ocean Beach, San Francisco, California, 20052007. U.S. Geological Survey Open-File Report 2008-1347. Reston VA: USGS. http://pubs.usgs.gov/of/2008/1347/

Barnard, P. L., J. Eshelman, L. Erikson, and D. M. Hanes. 2007. Coastal Processes Study at Ocean Beach, San Francisco, CA: Summary of Data Collection 2004-2006. USGS Open File Report 2007-1217. Reston, VA: USGS.

Barnard, P. L., D. M. Hanes, J. Lescinski and E. Elias. 2006. Monitoring and modeling nearshore dredge disposal for indirect beach nourishment, Ocean Beach, San Francisco. Proceedings, 2006 Coastal Engineering Conference, 4205-4217.

Beck, T. M., J. D. Rosati, and J. Rosati. 2012. An Update on Nearshore Berms in the Corps of Engineers: Recent Projects and Future Needs. ERDC/CHL CHETNXIV-10. Vicksburg, MS: U.S. Army Engineer Research and Development Center.

Birkemeier, W. A. 1985. Field data on seaward limit of profile change. Journal of Waterway, Port, Coastal and Ocean Engineering 111(3): 598-602.

Bodge, K. R. 1992. Representing equilibrium beach profiles with an exponential expression. Journal of Coastal Research 8(1): 47-55.

Bodge, K. R. 1994. Performance of nearshore berm disposal at Port Canaveral, Florida. Proceedings Dredging '94, 1182-1191. 
Bokuniewicz, H. J., J. Gebert, R. B. Gordon, P. Kaminsky, C. C. Pilbeam, M. Reed, and C. Tuttle. 1977. Field Study of the Effects of Storms on the Stability and Fate of Dredged Material in Subaqueous Disposal Areas. Technical Report D-77-22. Vicksburg, MS: U.S. Army Engineer Waterways Experiment Station.

Browder, A. E., and R. G. Dean. 200o. Monitoring and comparison to predictive models of the Perdido Key Beach Nourishment Project, Florida USA. Coastal Engineering 39(2-4): 173-191.

Brutsché, K. E. 2011. First Year Sedimentological Characteristics and Morphological Evolution of an Artificial Berm at Fort Myers Beach, Florida. Master's thesis. Tampa, FL: University of South Florida.

Brutsché, K. E. 2014. Evolution and Equilibration of Artificial Morphologic Perturbations in the Form of Nearshore Berm Nourishments along the Florida Gulf Coast. PhD dissertation. Tampa, FL: University of South Florida.

Brutsché, K. E., B. C. McFall, H. Li, J. E. McNinch, J. D. Ousley, J. A. Engle, and C. K. Maglio. 2017. Strategic nearshore placement of dredged sediment at Vilano Beach, Florida. Shore and Beach 85(3): 77-84

Brutsché, K. E., J. Rosati, C. E. Pollock, and B. C. McFall. 2016. Calculating Depth of Closure Using WIS Hindcast Data. ERDC/CHL CHETN-VI-45. Vicksburg, MS: U.S. Army Engineer Research and Development Center.

Brutsché, K. E., and P. Wang. 2012. First Year Morphological Evolution of an Artificial Berm at Fort Myers Beach, Florida. ERDC/CHL-CHETN-II-54. Vicksburg, MS: U.S. Army Engineer Research and Development Center.

Brutsché, K. E., P. Wang, T. M. Beck, J. D. Rosati, and K. R. Legault. 2014. Morphological evolution of a submerged artificial nearshore berm along a lowwave microtidal coast, Fort Myers Beach, west-central Florida, USA. Coastal Engineering 91: 29-44.

Bruun, P. 1954. Coast Erosion and the Development of Beach Profiles. Technical Memorandum No. 44. Beach Erosion Board. Washington, DC: U.S. Beach Erosion Board.

Burke, C. E., and M. C. Allison. 1992. Length and End Slope Considerations, Interim Design Guidance Update for Nearshore Berm Construction. Dredging Research Technical Notes DRP-5-06. Vicksburg, MS: U.S. Army Engineer Waterways Experiment Station.

Çelikoglu, Y., Y. Yüksel, and M. Kabdasli. 2006. Cross-shore sorting on a beach under wave action. Journal Coastal Research 22(3): 487-501.

Danek, L. J., G. R. Alther, P. P. Paily, R. G. Johnson, and F. T. Lovorn. 1978. Monitoring sedimentation at a disposal site. Proceedings of Coastal Zone'78, American Society of Civil Engineers, 1053-1063.

Danish Hydraulic Institute Staff. 2017. MIKE21 Flow Model, Hydrodynamic Model, User Guide. Hursholm, Denmark: Danish Hydraulic Institute. 
Dean, R. G. 1977. Equilibrium beach profiles: U.S. Atlantic and Gulf coasts. Ocean Engineering Report No. 12. Newark, DE: Department of Civil Engineering, University of Delaware.

Dean, R. G., and R. A. Dalrymple. 2002. Coastal Processes with Engineering Applications. Cambridge, UK: Cambridge University Press.

Dean, R. G., E. Otay, and P. A. Work. 1995. Perdido Key Beach Nourishment Project A Synthesis of Findings and Recommendations for Future Nourishments. UFL/COEL-95/o11. Gainesville, FL: University of Florida.

de San Román-Blanco, B., T. T. Coates, P. Holmes, A. J. Chadwick, A. Bradbury, T. E. Baldock, A. Pedrozo-Acuña, J. Lawrence, and J. Grüne. 2006. Large scale experiments on gravel and mixed beaches: Experimental procedure, data documentation and initial results. Coastal Engineering 53(4): 349-362.

Douglass, S. L. 1995. Estimating landward migration of neashore constructed sand mounds. Journal of Waterway, Port, Coastal, and Ocean Engineering 121(5): 247-250.

Douglass, S. L. 1996. Nearshore placement of sand. 25th International Conference on Costal Engineering, 3708-3721. https://doi.org/10.1061/9780784402429.286

Ebersole, B. A., M. A. Cialone, and M. D. Prater. 1986. Regional Coastal Processes Numerical Modeling System. Report 1, RCPWAVE--A Linear Wave Propagation Model for Engineering Use. Technical Report CERC-86-4. Vicksburg, MS: U.S. Army Engineer Waterways Experiment Station.

Finkl, C. W., and H. J. Walker. 2005. Beach nourishment. The Encyclopedia of Coastal Science. Edited by M. L. Schwartz. Dordrecht, 147-161. The Netherlands: Springer.

Foster, G. A., T. R. Healy, and W. P. de Lange. 1994. Sediment budget and equilibrium beach profiles applied to nourishment of an ebb tidal delta adjacent beach, Mt. Maunganui, New Zealand. Journal of Coastal Research 10(3): 564-575.

Frisch, A. A. 1979. A Model Study of the Effects of Bathymetry Alterations on Shoreline Wave Energy Dissipation. Master's thesis. Williamsburg, VA: College of William and Mary.

Gailani, J. Z., T. C. Lackey, and S. J. Smith. 2007. Application of the particle tracking model to predict far-field fate of sediment suspended by nearshore dredging and placement, Brunswick, Georgia. In Proceedings XVIII World Dredging Congress 2007. http://toc.proceedings.com/21826webtoc.pdf

Gailani, J. Z., and S. J. Smith. 2014. Nearshore placement of dredged material to support shoreline stabilisation. Proceedings of the Institution of Civil Engineers Maritime Engineering 167(2): 97-108.

Gailani, J. Z., S. J. Smith, L. Raad, and B. A. Ebersole. 2003. Savannah Harbor Entrance Channel: Nearshore Placement of Dredged Material Study. Vicksburg, MS: U.S. Army Research and Development Center, Report prepared for the U.S. Army Corps of Engineers Savannah District. 
Grasso, F., H. Michallet, E. Barthelemy, and R. Certain. 2009. Physical modeling of intermediate cross-shore beach morphology: Transients and equilibrium states. Journal of Geophysical Research 114(Co9001).

Grunnet, N. M., D. R. Walstra, and B. G. Ruessink. 2004. Process-based modeling of a shoreface nourishment. Coastal Engineering 51(7): 581-607.

Guannel, G., H. T. Ozkan-Haller, M. C. Haller, and J. T. Kirby. 2007. Influence of velocity moments on sand bar movement during CROSSTEX. Proceedings of the 6th International Symposium on Coastal Engineering and Science of Coastal Sediment Process, ASCE, 28-41.

Gunyakti, A. 1987. Beach preservation by means of offshore submerged mound of dredged materials. Coastal Zone '87, ASCE 2461-2471.

Hall, J. V. 1952. Artificially nourished and constructed beaches. Coastal Engineering Proceedings 3: 119-136.

Hall, J. V., and W. J. Herron. 1950. Test of the Nourishment of the Shore by Offshore Deposition of Sand, Long Branch, New Jersey. Technical Memorandum No. 17. Beach Erosion Board, Corps of Engineers, Department of the Army.

Hallermeier, R. J. 1978. Uses for a calculated limit depth to beach erosion. Proceedings of the $16^{\text {th }}$ International Conference on Coastal Engineering, American Society of Civil Engineers, 1493-1512.

Hallermeier, R. J. 1981a. Critical Wave Conditions for Sand Motion Initiation, Coastal Engineering. Technical Aid No. 81-10. Vicksburg, MS: Coastal Engineering Research Center.

Hallermeier, R. J. 1981b. A profile zonation for seasonal sand beaches from wave climate. Coastal Engineering 4(3): 253-277.

Hallermeier, R. J. 1983. Sand transport limits in coastal structure designs. Proceedings of Coastal Structures '83, American Society of Civil Engineers, 703-716.

Hamilton, D. G., B. A. Ebersole, E. R. Smith, and P. Wang. 2001. Development of a Large-Scale Laboratory Facility for Sediment Transport Research. ERDC/CHL TR-01-22. Vicksburg, MS: U.S. Army Engineer Research and Development Center.818353

Hands, E. B., and S. R. Deloach. 1984. An offshore Mound Constructed of Dredged Material. Proceedings of the Dredging and Dredged Material Disposal, DREDGING'84, American Society of Civil Engineers, 1030-1038.

Hands, E. B., and K. P. Bradley. 1990. Results of Monitoring the Disposal Berm at Sand Island, Alabama; Report I: Construction and First Year's Response. Technical Report DRP-90-2. Vicksburg, MS: U.S. Army Engineer Waterways Experiment Station.

Hands, E. B., and M. C. Allison. 1991. Mound migration in deeper water and methods of categorizing active and stable depths. Proceedings of Coastal Sediments '91, American Society of Civil Engineers, 1985-1999. 
Hanson, H., and N. C. Kraus. 2011. Long-term evolution of a long-term evolution model. Edited by T. M. Roberts, J. D. Rosati, and P. Wang. Proceedings, Symposium to Honor Dr. Nicholas C. Kraus. Journal of Coastal Research Special Issue No. 59: 118-129.

Hartman, G. L., A. Ogston, and M. Hanson. 1991. Analysis of transport processes on ocean disposal mound. Proceedings Coastal Sediments '91, American Society of Civil Engineers, 2027-2036.

Healy, T., C. Harms, and W. de Lange. 1991. Dredge spoil and inner shelf investigations off Tauranga Harbour, Bay of Plenty, New Zealand. Proceedings Coastal Sediments '91, American Society of Civil Engineers, 203-2051.

Hoekstra, P., K. T. Houwman, A. Kroon, B. G. Ruessink, J. A. Roelvink, and R. Spanhoff. 1996. Morphological development of the Terschelling shoreface nourishment in response to hydrodynamics and sediment transport processes. Proceedings of Coastal Engineering 1996, American Society of Civil Engineers, 2897-2910.

Holmes, P., T. E. Baldock, R. T. Chan, and M. L. Neshaei. 1996. Beach evolution under random waves. In Proc. 25th Int. Conf. Coastal Eng. 3006-3018. Orlando, Florida.

Hwung, H.-H., Z.-C. Huang, and K.-S. Hwang. 2010. An experimental study of the crossshore evolution of artificial submerged sand bars. Coastal Engineering Journal 52(4): 261-285.

Johnson, B. D. 1990. User's Guide for Models of Dredged Material in Open Water, Environmental Laboratory. Technical Report TR-D-90-5. Vicksburg, MS: U.S. Army Waterways Experiment Station.

Johnson, H. K., C. M. Appendini, M. Soldati, B. Elfrink, and P. Sorensen. 2001. Numerical modelling of morphological changes due to shoreface nourishment. Proceedings of Coastal Dynamics '01, 878-887.

Johnson, B. D., and E. R. Smith. 2012. Material placement in the nearshore: Laboratory and numerical model investigation. Coastal Engineering Proceedings.

Johnson, C., and P. A. Work. 2005. Nearshore dredged spoil mounds for beach erosion prevention and mitigation. Proceedings of Fourth Conference on Coastal Dynamics 2001, 433-442.

Juhnke, L., T. Mitchell, and M. J. Piszker. 1990. Construction and Monitoring of Nearshore Placement of Dredged Material at Silver Strand State Park, San Diego, California. Dredging Research Technical Note DRP-1-01. Vicksburg, MS: U.S. Army Engineer Waterways Experiment Station.

Kraus, N. C., and M. Larson. 1991. NMLONG: Numerical Model for Simulating the Longshore Current: Report 1 - Model Development and Tests. Technical Report DRP-91-1. Vicksburg, MS: U.S. Army Engineer Waterways Experiment Station.

Kraus, N. C., M. Larson, and D. L. Kriebel. 1991. Evaluation of beach erosion and accretion predictors. Proc. Coastal Sediments '91, ASCE, 572-587. 
Kraus, N. C., J. M. Smith, and C. K. Sollitt. 1992. SUPERTANK laboratory data collection project. Proceedings of $23^{\text {rd }}$ International Conference on Coastal Engineering, ASCE, 2191-2204).

Kraus, N. C., M. Larson, and R. Wise. 1998. Depth of Closure in Beach Fill Design. CETN II-40. Vicksburg, MS: U.S. Army Engineer Waterways Experiment Station.

Kriauciuniene, J., B. Gailiusis, and E. Rimaviciute. 2006. Modelling of shoreface nourishment in the Lithuanian nearshore of the Baltic Sea. Geologija 53: 28-37.

Kroon, A., P. Hoekstra, K. T. Houwman, and G. Ruessink. 1994. Morphological monitoring of a shoreface nourishment-NOURTEC experiment at Terschelling, The Netherlands. 24th International Conference on Coastal Engineering, 22222236.

Larson, M., and B. A. Ebersole. 1999. An Analytical Model to Predict the Response of Mounds Placed in the Offshore. ERDC/CHL CETN-II-42. Vicksburg, MS: U.S. Army Engineer Research and Development Center.

Larson, M., and N. C. Kraus. 1989. SBEACH: Numerical Model for Simulating StormInduced Beach Change, Report 1: Empirical Foundation and Model Development. Technical Report CERC-89-9. Vicksburg, MS: U.S. Army Engineer Research and Development Center.

Larson, M., and N. C. Kraus. 1992. Analysis of Cross-shore Movement of Natural Longshore Bars and Material Placed to Create Longshore Bars. Technical Report DRP-92-5. Vicksburg, MS: U.S. Army Engineer Waterways Experiment Station.

Larson, M., and N. C. Kraus. 1994. Temporal and spatial scales of beach profile change, Duck, North Carolina. Marine Geology 117(1-4): 75-94.

Larson, M., N. C. Kraus, and M. R. Byrmes. 1990. SBEACH: Numerical Model for Simulating Storm-Induced Beach Change, Report 2: Numerical Formulation and Model Tests. Technical Report CERC-89-9. Vicksburg, MS: U.S. Army Engineer Waterways Experiment Station.

Larson M., B. Camenen, and P. T, Nam. 2011. A unified sediment transport model for inlet application. Proceedings, Symposium to Honor Dr. Nicholas C. Kraus. Edited by T. M. Roberts, J. D. Rosati, and P. Wang. Journal of Coastal Research Special Issue 59: 27-38.

Lin, L., H. Li, M. E. Brown, F. Wu, and L. Andes. 2013. Pilot Study Evaluating Nearshore Sediment Placement Sites, Noyo Harbor, CA. ERDC/CHL TR-13-2. Vicksburg, MS: U.S. Army Engineer Research and Development Center.

Lin L., Z. Demirbilek, and H. Mase. 2011. Recent capabilities of CMS-Wave: A coastal wave model for inlets and navigation projects. Proceedings, Symposium to Honor Dr. Nicholas C. Kraus. Edited by T. M. Roberts, J. D. Rosati, and P. Wang. Journal of Coastal Research Special Issue No. 59: 7-14. 
Lin, L., Z. Demirbilek, H. Mase, J. Zheng, and F. Yamada. 2008. CMS-Wave: A Nearshore Spectral Wave Processes Model for Coastal Inlets and Navigation Projects. ERDC/CHL-TR-08-13. Vicksburg, MS: U.S. Army Engineer Research and Development Center.

Lin L., J. Rosati, and Z. Demirbilek. 2012. CMS-Wave Model: Part 5. Full-plane Wave Transformation and Grid Nesting. ERDC/CHL CHETN-IV-81. Vicksburg, MS: U.S. Army Engineer Research and Development Center.

Luettich, R. A., J. J. Westerink, and N. W. Scheffner. 1992. ADCIRC: An Advanced ThreeDimensional Circulation Model for Shelves, Coasts, and Estuaries; Report 1, Theory and Methodology of ADCIRC-2DDI and ADCIRC-3DL. Technical Report DRP-92-6. Vicksburg, MS: U.S. Army Engineer Research and Development Center.

MacDonald, N. J., M. H. Davies, A. K. Zundel, J. D. Howlett, Z. Demirbilek, J. Z. Gailani, T. C. Lackey, and S. J. Smith. 2006. PTM: Particle Tracking Model Report 1: Model Theory, Implementation, and Example Applications. TR-06-20. Vicksburg, MS: U.S. Army Engineer Research and Development Center.

Mesa, C. 1996. Nearshore berm performance at Newport Beach, California, USA. In Proceedings of Coastal Engineering 1996, American Society of Civil Engineers, 4636-4649.

McComb, P. J., and K. P. Black. 2001. Dynamics of nearshore dredged-sand mound on a rocky, high-energy coast. Journal of Coastal Research SI34: 550-563.

McFall, B. C., C. E. Pollock, and K. E. Brutsché. 2015. Evaluating Sediment Mobility for Milford, CT Nearshore Placement. ERDC/CHL LR-15-7. Vicksburg, MS: U.S. Army Research and Development Center.

McFall, B. C., S. J. Smith, C. E. Pollock, J. Rosati, and K. E. Brutsché. 2016. Evaluating Sediment Mobility for Siting Nearshore Berms. ERDC/CHL-CHETN-IV-108. Vicksburg, MS: U.S. Army Engineer Research and Development Center.

McLellan, T. N. 1988. Nearshore placement techniques for dredged material. Proceedings of $21^{\text {st }}$ Annual Dredging Seminar, 24-35.

McLellan, T. N. 1990a. Nearshore mound construction using dredged material. Journal of Coastal Research 7: 99-107.

McLellan, T. N. 1990b. Engineering Design Considerations for Nearshore Berms. Dredging Research Technical Notes DRP-5-01. Vicksburg, MS: U.S. Army Engineer Waterways Experiment Station.

McLellan, T. N., and N. C. Kraus. 1991. Design guidance for nearshore berm construction. Proceedings of Coastal Sediments '91, American Society of Civil Engineers, 2000-2011.

McLellan, T. N., N. C. Kraus, and C. E. Burke. 1990. Interim Design Guidance for Nearshore Berm Construction. Dredging Research Technical Notes DRP-5-02. Vicksburg, MS: U.S. Army Engineer Waterways Experiment Station. 
Nielsen, P. 1992. Coastal bottom boundary layers and sediment transport. Advanced Series on Ocean Engineering, Vol. 4. Singapore: World Scientific.

Otay, E. N. 1994. Long-Term Evolution of Nearshore Disposal Berms. PhD dissertation. University of Florida.

Otay, E. N. 1995. Monitoring results of a nearshore disposal berm. Proceedings Coastal Dynamics '95, American Society of Civil Engineers, 547-558.

Pollock, C. B., and M. C. Allison. 1993. Berm Crest Width Considerations, Iterim Design Guidance Update for Nearshore Berm Construction. Dredging Research Technical Notes DRP-5-08. Vicksburg, MS: U.S. Army Engineer Waterways Experiment Station.

Pollock, C. B., W. R. Curtis, and H. R. Moritz. 1998. Numerical Methods for NearshoreBerm Evaluation, St. Johns County, Florida. Technical Report CHL-98-12. Vicksburg, MS: U.S. Army Engineer Research and Development Center.

Reed, C. W., M. E. Brown, A. Sánchez, W. Wu, and A. M. Buttolph. 2011. The Coastal Modeling System Flow model (CMS-Flow): Past and present. Proceedings, Symposium to Honor Dr. Nicholas C. Kraus. Edited by T. M. Roberts, J. D. Rosati, and P. Wang. Journal of Coastal Research Special Issue No. 59: 1-6.

Resio, D. T. 1987. Shallow water waves I: Theory. Journal of Waterway, Port, Coastal and Ocean Engineering, ASCE 113(3): 264-281.

Resio, D. T. 1988. A steady state wave model for coastal applications. Proceedings of the $21^{\text {st }}$ Coastal Engineering Conference, ASCE, 929-940.

Roelvink, J. A., Th. J. G. P. Meijer, K. T. Houwman, R. Bakker, and R. Spanhoff. 1996. Field validation and application of a coastal profile model. Proceedings of Coastal Dynamics '95, ASCE, New York, 818-828.

Rosati, J. D., R. A. Wise, N. C. Kraus, and M. Larson. 1993. SBEACH: Numerical Model for Simulating Storm-Induced Beach Change, Report 3: User's Manual. Instruction Report CERC-93-2. Vicksburg, MS: U.S. Army Engineer Waterways Experiment Station.

Sánchez, A., W. Wu, T. M. Beck, H. Li, J. Rosati III, R. Thomas, J. D. Rosati, Z. Demirbilek, M. Brown, and C. W. Reed. 2011a. Verification and Validation of the Coastal Modeling System, Report 3, CMS Flow: Hydrodynamics. ERDC/CHLTR-11-10. Vicksburg, MS: U.S. Army Engineer Research and Development Center.

Sánchez, A., W. Wu, T. M. Beck, H. Li, J. D. Rosati, Z. Demirbilek, and M. Brown. 2011b. Verification and Validation of the Coastal Modeling System, Report 4, CMS Flow: Sediment Transport and Morphology Change. ERDC/CHL-TR-11-10. Vicksburg, MS: U.S. Army Engineer Research and Development Center.

Sánchez, A., W. Wu, H. Li, M. Brown, C. Reed, J. D. Rosati, and Z. Demirbilek. 2014. Coastal Modeling System: Mathematical Formulations and Numerical Methods, ERDC/CHL TR-14-2. Vicksburg, MS: U.S. Army Engineer Research and Development Center. 
Scheffner, N. W. 1991. A systematic analysis of disposal site stability. Proceedings Coastal Sediments '91, American Society of Civil Engineers, 2012-2026.

Scheffner, N. W., M. M. Thevenot, J. R. Tallent, and J. M. Mason. 1995. LTFATE: A Model to Investigate the Long Term Fate and Stability of Dredged Material Disposal Sites; User's Guide. Instruction Report DRP-95-1. Vicksburg, MS: U.S. Army Engineer Waterways Experiment Station.

Schwartz, R. K., and F. R. Musialowski. 1977. Nearshore disposal: Onshore sediment transport. In Proceedings Coastal Sediments '77, American Society of Civil Engineers, 85-101.

Smith, A. W., and L. A. Jackson. 1990. The siting of beach nourishment placement. Shore and Beach 58: 17-24.

Smith, E. R., R. Permenter, M. C. Mohr, and S. A. Chader. 2015. Modeling of Nearshore Placed Dredged Material. ERDC/CHL TR-15-9. Vicksburg, MS: U.S. Army Engineer Research and Development Center.

Smith, J. M., A. R. Sherlock, and D. T. Resio. 2001. STWAVE: Steady State Spectral Wave Model, User's Guide for STWAVE Version 3.o. ERDC/CHL SR-01-01. Vicksburg, MS: U.S. Army Engineer Research and Development Center.

Smith, S. J., J. Marsh, and T. Puckette. 2007. Analysis of fluorescent sediment tracer for evaluating nearshore placement of dredged material. Proceedings XVIII World Dredging Congress 2007, 1345-1358.

Soulsby, R. L. 1997. Dynamics of Marine Sands: A Manual for Practical Applications. London: Thomas Telford.

Srisuwan, C., P. A. Work, S. Karasu, and I. Özölçer. 2014. Beach profile model with sizeselective sediment transport. I: Laboratory experiment and sensitivity study. J. of Waterway, Port, Coastal, and Ocean Eng. 104(2): 04014032.

U.S. Army Corps of Engineers (USACE). 1994. Application of SBEACH to Coastal Projects. CETN II-33. Vicksburg, MS: Coastal Engineering Research Center.

Van Duin, M. J. P., N. R. Wiersma, D. J. R. Walstra, L. C. van Rijn, and M. J. F. Stive. 2004. Nourishing the shoreface: Observations and hindcasting of the Egmond Case, The Netherlands. Coastal Engineering 51(8-9): 813-837.

Van Rijn, L. C. 1984a. Sediment transport, part I: Bed Load Transport. Journal of Hydraulic Engineering, ASCE 110(10): 1431-1456.

Van Rijn, L. C. 1984b. Sediment transport, Part II: Suspended load transport. Journal of Hydraulic Engineering, ASCE 110(11): 1613-1641.

Vera-Cruz, D. 1972. Artificial Nourishment of Copacabana Beach. Proceedings of $13^{\text {th }}$ International Conference on Coastal Engineering, ASCE, 1451-1463.

Wang, P., K. E. Brutsché, T. M. Beck, J. D. Rosati, and L. S. Lillycrop. 2013. Initial Morphologic Evolution of Perdido Key Berm Nourishment, Florida. ERDC/CHL CHETN-IV-89. Vicksburg, MS: U.S. Army Engineer Research and Development Center. 
Wang, P., and R. A. Davis, Jr. 1998. A beach profile model for a barred coast - case study from Sand Key, west-central Florida. Journal of Coastal Research 14(3): 981991.

Wang, P., and R. A. Davis, Jr. 1999. Depth of closure and the equilibrium beach profile a case study from Sand Key, west-central Florida. Shore and Beach 67: 33-42.

Wang, P., B. A. Ebersole, and E. R. Smith. 2003. Beach-profile evolution under spilling and plunging breakers. Journal of Waterway, Port, Coastal, and Ocean Engineering 129(1).

Wang, P., and N. C. Kraus. 2005. Beach profile equilibrium and patterns of wave decay and energy dissipation across the surf zone elucidated in a large-scale laboratory experiment. Journal of Coastal Research 21(3): 522-534.

Williams, G. L., and T. L. Prickett. 1998. Planning Considerations for Nearshore Placement of Mixed Dredged Sediment. DOER Technical Notes Collection ERDC TN-DOER-N3. Vicksburg, MS: U.S. Army Engineer Waterways Experiment Station.

Work, P. A., ASCE, and E. N. Otay. 1996. Influence of nearshore berm on beach nourishment. Proceedings of 25th International Conference on Coastal Engineering, 3722-3735.

Zwamborn, J. A., G. A. W. Fromme, and J. B. Fitzpatrick. 1970. Underwater mound for the protection of Durban's beaches. Proceedings of 12th International Conference on Coastal Engineering, 975-994. 


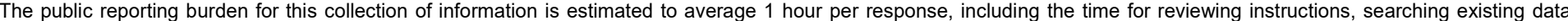

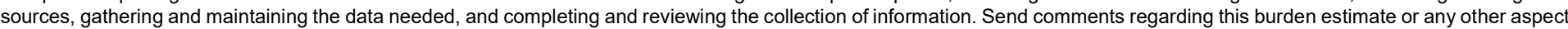

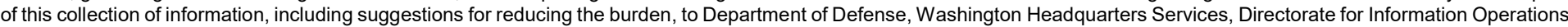

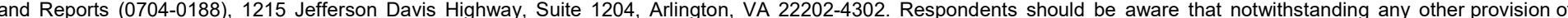
law, no person shall be subject to any penalty for failing to comply with a collection of information if it does not display a currently valid OMB control number.

PLEASE DO NOT RETURN YOUR FORM TO THE ABOVE ADDRESS.

\begin{tabular}{l|l|l|l}
$\begin{array}{l}\text { 1. REPORT DATE } \\
\text { April } 2019\end{array}$ & $\begin{array}{l}\text { 2. REPORT TYPE } \\
\text { Final Report }\end{array}$ & 3. DATES COVERED (From - To)
\end{tabular}

\section{TITLE AND SUBTITLE}

Literature Review of Nearshore Berms 5a. CONTRACT NUMBER

5b. GRANT NUMBER

5c. PROGRAM ELEMENT NUMBER

Katherine E. Brutsché, Brian C. McFall, Duncan B. Bryant, and Ping Wang

\section{5d. PROJECT NUMBER}

5e. TASK NUMBER

5f. WORK UNIT NUMBER

476927

\section{PERFORMING ORGANIZATION REPORT NUMBER} University of South Florida 4202 E. Fowler Ave. Tampa, FL 33620

ERDC/CHL SR-19-2

10. SPONSOR/MONITOR'S ACRONYM(S) ERDC

11. SPONSOR/MONITOR'S REPORT NUMBER(S)

\section{DISTRIBUTION/AVAILABILITY STATEMENT}

Approved for public release; distribution is unlimited.

\section{SUPPLEMENTARY NOTES}

\section{ABSTRACT}

This Coastal and Hydraulics Engineering special report is a general overview of the current state of nearshore berm placement research. The report describes current design guidance for nearshore berm placement, as well as the major findings of existing numerical and physical modeling studies. Field experiments are also summarized. Numerical and physical models are important as they help to illustrate in greater detail the morphological evolution and hydrodynamic effects the berm has on the surrounding area. Physical models allow for two- and three-dimensional illustration of these concepts. Field studies show that onshore migration of active berms occurs and the tendency of nearshore berms to act as a submerged breakwater. Although many field and modeling studies exist to assess the morphologic and sedimentologic evolution of berms, a need for more detailed understanding of the processes associated with these types of nourishments still exists. More data to predict where material is going, how the existing adjacent morphologic features respond to the placement, and how long the material will remain in place (or its intended location) are necessary to answer stakeholder questions for these types of placements.

\section{SUBJECT TERMS}

Beach nourishment, Breakwaters, Coastal sediments, Littoral drift, Sedimentation and deposition, Sediment transport, Shore protection

\section{SECURITY CLASSIFICATION OF:}

\begin{tabular}{l|l|l|}
\hline a. REPORT & b. ABSTRACT & c. THIS PAGE \\
Unclassified & Unclassified & Unclassified
\end{tabular}

17. LIMITATION OF
ABSTRACT
SAR

18. NUMBER OF PAGES

59 19a. NAME OF RESPONSIBLE PERSON

Katherine E. Brutsché

19b. TELEPHONE NUMBER (Include area code) 601-634-4174 